OPEN ACCESS

Edited by:

Fan Wu,

Fudan University, China

Reviewed by:

Marcos Lopez,

University of Chicago, United States

Simona Martinotti,

Università degli Studi del Piemonte

Orientale, Italy

Ana Cipak Gasparovic,

Ructer Bošković Institute, Croatia

*Correspondence:

Anitra C. Carr

anitra.carr@otago.ac.nz

Specialty section:

This article was submitted to Clinical and Translational Physiology,

a section of the journal

Frontiers in Physiology

Received: 28 April 2018

Accepted: 06 August 2018

Published: 23 August 2018

Citation:

Carr AC and Cook J (2018) Intravenous Vitamin C for Cancer Therapy - Identifying the Current

Gaps in Our Knowledge.

Front. Physiol. 9:1182.

doi: 10.3389/fphys.2018.01182

\section{Intravenous Vitamin C for Cancer Therapy - Identifying the Current Gaps in Our Knowledge}

\author{
Anitra C. Carr ${ }^{1 *}$ and John Cook ${ }^{2}$ \\ ${ }^{1}$ Department of Pathology and Biomedical Science, University of Otago, Christchurch, New Zealand, ${ }^{2}$ New Brighton Health \\ Care, Christchurch, New Zealand
}

The use of intravenous vitamin C (IVC) for cancer therapy has long been an area of intense controversy. Despite this, high dose IVC has been administered for decades by complementary health care practitioners and physicians, with little evidence base resulting in inconsistent clinical practice. In this review we pose a series of questions of relevance to both researchers and clinicians, and also patients themselves, in order to identify current gaps in our knowledge. These questions include: Do oncology patients have compromised vitamin $\mathrm{C}$ status? Is intravenous the optimal route of vitamin $\mathrm{C}$ administration? Is IVC safe? Does IVC interfere with chemotherapy or radiotherapy? Does IVC decrease the toxic side effects of chemotherapy and improve quality of life? What are the relevant mechanisms of action of IVC? What are the optimal doses, frequency, and duration of IVC therapy? Researchers have made massive strides over the last 20 years and have addressed many of these important aspects, such as the best route for administration, safety, interactions with chemotherapy, quality of life, and potential mechanisms of action. However, we still do not know the answers to a number of fundamental questions around best clinical practice, such as how much, how often and for how long to administer IVC to oncology patients. These questions point the way forward for both basic research and future clinical trials.

Keywords: vitamin C, ascorbate, intravenous vitamin C, cancer, chemotherapy, pharmacokinetics, enzyme cofactor, quality of life

\section{INTRODUCTION}

Over the years, numerous epidemiological studies have highlighted a decreased incidence of cancer and improved survival in patients with higher dietary intakes of vitamin $\mathrm{C}$ or higher plasma levels of the vitamin (Carr and Frei, 1999b; Harris et al., 2014). Although vitamin C is often considered a good marker of fruit and vegetable intake (Block et al., 2001), the vitamin has essential functions within the body, including integral roles in various anti-cancer mechanisms (Du et al., 2012). Because of the pleiotropic functions of vitamin C, optimizing its levels in the body through diet and supplementation is likely to be of benefit to oncology patients. In support of this premise, studies in a vitamin C-requiring mouse model indicate that oral vitamin C supplementation of these animals can impair the development of tumors and can also increase the rejection rate of implanted tumor cells (Campbell et al., 2016a; Cha et al., 2016). This suggests an important role for vitamin C in host defense against cancer. 
Treatment of cancer, in contrast, is thought to require much higher doses of vitamin $\mathrm{C}$ than normal dietary intakes (Parrow et al., 2013). In fact, high dose intravenous vitamin C (IVC) has been administered by physicians for many decades as a complementary and alternative therapy for oncology patients (Padayatty et al., 2010). This practice has continued despite significant controversy in the field as a result of two high profile Mayo Clinic trials carried out in the late 1970s which debunked the initially encouraging findings of Cameron and Pauling (1976, 1978; Creagan et al., 1979; Moertel et al., 1985). Due to the paucity of a strong evidence base for informing appropriate clinical practice, there are significant inconsistencies in administration of IVC therapy to oncology patients (Padayatty et al., 2010). These include huge variability in the dose, frequency, and duration of vitamin $\mathrm{C}$ administration.

Research in the 1990s highlighting the important differences between oral and IVC pharmacokinetics resulted in a surge of new research in the IVC field with numerous in vitro, preclinical and clinical studies being undertaken (Parrow et al., 2013; Fritz et al., 2014). The in vitro studies have provided useful insights into potential mechanisms of action and pre-clinical studies have indicated promising efficacy of IVC, however, clinical studies have so far been limited primarily to Phase I safety and pharmacokinetic trials (Du et al., 2012; Parrow et al., 2013). As a result of study design issues with many of the earlier clinical trials there remains controversy as to the efficacy of IVC in the treatment of cancer (Wilson et al., 2014). Many of these trials recruited terminal or end-stage patients, for whom any sort of treatment is unlikely to have an effect, and they often recruited cohorts with mixed cancers, which may respond differentially to IVC depending on the underlying mechanisms involved.

In this review, we pose a series of questions, both clinically relevant and patient centered, related to IVC use in cancer therapy in order to identify the current gaps in our knowledge. Although many of these questions have been adequately addressed, some require further research in order to provide the essential data required to inform good clinical practice.

\section{Q1. DO ONCOLOGY PATIENTS HAVE COMPROMISED VITAMIN C STATUS?}

Vitamin C supports many important biological functions through its action as an electron donor (Du et al., 2012), however, the vitamin $\mathrm{C}$ status of oncology patients is often not assessed in clinical trials or in clinical practice. Many studies (shown in Table 1) have consistently shown that patients with cancer have lower mean plasma vitamin C status than healthy controls (Torun et al., 1995; Choi et al., 1999; Mahdavi et al., 2009; Sharma et al., 2009; Emri et al., 2012; Mehdi et al., 2013; Huijskens et al., 2016), and a large proportion of them present with hypovitaminosis $\mathrm{C}(<23 \mu \mathrm{mol} / \mathrm{L})$ and outright deficiency $(<11 \mu \mathrm{mol} / \mathrm{L}$ ) (Anthony and Schorah, 1982; Fain et al., 1998; Mayland et al., 2005; Riordan et al., 2005; Hoffer et al., 2015; Liu et al., 2016; Shenoy et al., 2017). Although other case control studies have confirmed lower vitamin C status in patients with cancer (Khanzode et al., 2003; Gupta et al., 2009), their control values were also quite low indicating possible issues with sample collection and/or analysis (Pullar et al., 2018). Severity of the disease also appears to impact on vitamin $\mathrm{C}$ status with the proportion of lymphoma patients with hypovitaminosis $\mathrm{C}$ being significantly elevated for those with high-burden disease (Shenoy et al., 2017). Furthermore, patients with higher stage breast and cervical cancers had significantly lower vitamin $\mathrm{C}$ status than patients with lower stage disease (Ramaswamy and Krishnamoorthy, 1996; Khanzode et al., 2004). Ex vivo studies indicate that tumors from patients with colorectal cancer contained lower vitamin $\mathrm{C}$ concentrations than matched normal tissue (Kuiper et al., 2014a), and higher grade colorectal and endometrial tumors had proportionately less vitamin $\mathrm{C}$ than lower grade tumors (Kuiper et al., 2010, 2014a).

This observational data supports the premise that oncology patients have compromised vitamin C status, which is likely due to enhanced metabolic turnover as a result of oxidative and inflammatory aspects of the disease process (Reuter et al., 2010). Enhanced oxidative stress and pro-inflammatory biomarkers can also result from chemotherapy (Hunnisett et al., 1995; Nannya et al., 2014). Administration of IVC to oncology patients results in lower circulating vitamin $\mathrm{C}$ levels compared with administration of the same amount to healthy controls (Mikirova et al., 2013). The finding that oncology patients have a higher requirement for vitamin $C$ is thought to indicate a lower body pool and/or the higher oxidative and pro-inflammatory status of these patients, as indicated by elevated lipid oxidation products or C-reactive protein concentrations (Torun et al., 1995; Mayland et al., 2005; Mahdavi et al., 2009; Sharma et al., 2009; Mehdi et al., 2013; Mikirova et al., 2013). It is interesting to note that animals which can synthesize their own vitamin $\mathrm{C}$ in their livers increase their endogenous vitamin $\mathrm{C}$ levels when under a tumor burden suggesting enhanced requirements (Campbell et al., 2015; Cha et al., 2016).

There is evidence that adjunctive cancer therapies may impact negatively on vitamin C status (Table 2). It has been noted that administration of some anticancer therapies, such as cisplatin, fluorouracil, nilotinib, and interleukin-2, can significantly lower the vitamin C status of oncology patients and result in scurvylike symptoms in some cases (Marcus et al., 1991; Fain et al., 1998; Weijl et al., 1998; Alexandrescu et al., 2009; Oak et al., 2016). Chemotherapy drugs such as cisplatin are known to generate off-target oxidative stress which could contribute to the depletion of vitamin C (Chirino and Pedraza-Chaverri, 2009). Discontinuation of the chemotherapy or administration of supplemental vitamin $\mathrm{C}$ to these patients resolved the deficiency symptoms (Fain et al., 1998; Alexandrescu et al., 2009; Oak et al., 2016). Patients with hematopoietic cancers typically undergo conditioning with multiple chemotherapy agents and a number of studies have shown significantly lower vitamin C status following the conditioning regimens (Hunnisett et al., 1995; Goncalves et al., 2009; Nannya et al., 2014; Huijskens et al., 2016; Liu et al., 2016; Rasheed et al., 2017). Although plasma vitamin C levels appear to return to baseline values approximately 1 month following chemotherapy (Mehdi et al., 2013; Rasheed et al., 2017), these values are still well below optimal. Administration of IVC to these patients has been shown to increase their circulating vitamin C levels and decrease markers of lipid oxidation (Hunnisett et al., 1995; Jonas et al., 2000). 
TABLE 1 | Vitamin C levels in plasma or serum of oncology patients.

\begin{tabular}{|c|c|c|c|}
\hline Study types & Study cohorts & Vitamin C levels & Reference \\
\hline Case control & $\begin{array}{l}22 \text { controls } \\
57 \text { patients with cancer (gastrointestinal, head and neck, lung) }\end{array}$ & $\begin{array}{l}\text { Controls: } 51 \mu \mathrm{mol} / \mathrm{L} \\
\text { Cases: } 10 \mu \mathrm{mol} / \mathrm{L}^{* *}\end{array}$ & Mahdavi et al., 2009 \\
\hline Case control & $\begin{array}{l}156 \text { controls } \\
208 \text { patients with cancer (breast, head and neck, genitourinary, lung, } \\
\text { gastrointestinal, etc.) }\end{array}$ & $\begin{array}{l}\text { Controls: } 50 \mu \mathrm{mol} / \mathrm{L} \\
\text { Cases: } 23 \mu \mathrm{mol} / \mathrm{L}^{*}\end{array}$ & Torun et al., 1995 \\
\hline Case control & $\begin{array}{l}50 \text { controls } \\
50 \text { patients with multiple myeloma }\end{array}$ & $\begin{array}{l}\text { Controls: } 81 \mu \mathrm{mol} / \mathrm{L} \\
\text { Cases: } 30 \mu \mathrm{mol} / \mathrm{L}^{* *}\end{array}$ & Sharma et al., 2009 \\
\hline Case control & $\begin{array}{l}30 \text { controls } \\
30 \text { patients with multiple myeloma }\end{array}$ & $\begin{array}{l}\text { Controls: } 52 \mu \mathrm{mol} / \mathrm{L} \\
\text { Cases: } 39 \mu \mathrm{mol} / \mathrm{L}^{* *}\end{array}$ & Mehdi et al., 2013 \\
\hline Case control & $\begin{array}{l}83 \text { controls } \\
42 \text { patients with malignant mesothelioma }\end{array}$ & $\begin{array}{l}\text { Controls: } 49 \mu \mathrm{mol} / \mathrm{L} \\
\text { Cases: } 30 \mu \mathrm{mol} / \mathrm{L}^{* *}\end{array}$ & Emri et al., 2012 \\
\hline Case control & $\begin{array}{l}76 \text { controls } \\
42 \text { patients with hematological malignancies }\end{array}$ & $\begin{array}{l}\text { Controls: } 65 \mu \mathrm{mol} / \mathrm{L} \\
\text { Cases: } 21 \mu \mathrm{mol} / \mathrm{L}^{* * *} \\
19 \%<11 \mu \mathrm{mol} / \mathrm{L}\end{array}$ & Huijskens et al., 2016 \\
\hline Single arm & $\begin{array}{l}34 \text { patients with lymphoma } \\
14 \text { high burden disease } \\
20 \text { low burden disease }\end{array}$ & $\begin{array}{l}29 \%<23 \mu \mathrm{mol} / \mathrm{L} \\
64 \%<23 \mu \mathrm{mol} / \mathrm{L}^{* *} \\
5 \%<23 \mu \mathrm{mol} / \mathrm{L}\end{array}$ & Shenoy et al., 2017 \\
\hline Single arm & $\begin{array}{l}50 \text { patients with cancer (brain, breast, bronchial, urogenital, prostate, } \\
\text { gastrointestinal, etc.) }\end{array}$ & $\begin{array}{l}72 \%<23 \mu \mathrm{mol} / \mathrm{L} \\
30 \%<11 \mu \mathrm{mol} / \mathrm{L}\end{array}$ & Mayland et al., 2005 \\
\hline Single arm & 22 patients with cancer (mostly colon) & $\begin{array}{l}73 \%<50 \mu \mathrm{mol} / \mathrm{L} \\
60 \%<23 \mu \mathrm{mol} / \mathrm{L} \\
50 \%<11 \mu \mathrm{mol} / \mathrm{L}\end{array}$ & Riordan et al., 2005 \\
\hline Single arm & 12 patients with cancer (mostly colon and rectum) & $\begin{array}{l}67 \%<50 \mu \mathrm{mol} / \mathrm{L} \\
8 \%<11 \mu \mathrm{mol} / \mathrm{L}\end{array}$ & Hoffer et al., 2015 \\
\hline Single arm & 24 patients with hematopoietic cancers & $\begin{array}{l}92 \%<26 \mu \mathrm{mol} / \mathrm{L} \\
58 \%<11 \mu \mathrm{mol} / \mathrm{L}\end{array}$ & Liu et al., 2016 \\
\hline Single arm & 139 patients with lung cancer & $\begin{array}{l}70 \%<20 \mu \mathrm{mol} / \mathrm{L} \\
30 \%<6 \mu \mathrm{mol} / \mathrm{L}\end{array}$ & Anthony and Schorah, 1982 \\
\hline
\end{tabular}

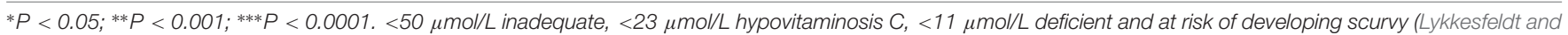
Poulsen, 2010).

\section{Q2. IS IV THE OPTIMAL ROUTE FOR VITAMIN C ADMINISTRATION?}

Much of the controversy around vitamin C use in cancer therapy has arisen from early misunderstandings around the pharmacokinetics of oral and IVC. In the mid 1970s Cameron and Pauling $(1976,1978)$ published findings from 100 terminal cancer patients who had been administered $10 \mathrm{~g} / \mathrm{d}$ IVC for approximately 10 days, followed by $10 \mathrm{~g} / \mathrm{d}$ oral vitamin C thereafter. Their work showed significantly enhanced survival in these patients compared with two retrospective cohorts of 1,000 patients who did not receive vitamin C. Subsequently, researchers at the Mayo Clinic attempted to reproduce these results with two randomized controlled trials (RCTs) carried out in 123 patients with advanced malignancies and 100 patients with advanced colorectal cancer (Creagan et al., 1979; Moertel et al., 1985). Neither study showed a significant survival advantage in the patients who received vitamin $\mathrm{C}$.

The negative results of the Mayo Clinic RCTs relegated the use of vitamin $\mathrm{C}$ to the arena of complementary and alternative medicine (Padayatty et al., 2010). It wasn't until the mid 1990s, when the seminal work by Mark Levine's group highlighted the dramatic differences between the pharmacokinetics of oral and IVC, that the discrepancies between the original Cameron and Pauling studies and the Mayo Clinic RCTs were explained
(Levine et al., 1996). While Cameron and Pauling (1976, 1978) had used IVC with subsequent oral maintenance, the Mayo Clinic RCTs comprised divided daily doses of oral vitamin C only (Creagan et al., 1979; Moertel et al., 1985). Intestinal uptake of oral vitamin $\mathrm{C}$ is regulated via the sodium-dependent vitamin C transporter-1 (SVCT1) (Savini et al., 2008), which is bypassed with IVC administration, resulting in significantly higher plasma concentrations (Levine et al., 1996). Peak plasma concentrations from oral ingestion rarely exceed $200 \mu \mathrm{mol} / \mathrm{L}$ (Padayatty et al., 2004), however, IVC administration can result in peak plasma concentrations of $20 \mathrm{mmol} / \mathrm{L}$ (Table 3 ). These high concentrations are relatively transient, however, due to rapid clearance by the kidneys, resulting in a half-life of about $2 \mathrm{~h}$ in circulation (Stephenson et al., 2013; Nielsen et al., 2015). The realization that IVC may be more effective than oral vitamin $\mathrm{C}$ in oncology patients sparked a surge of new research in the field over the past 20 years, particularly around plausible mechanisms of action (Parrow et al., 2013; Fritz et al., 2014).

\section{Q3. IS IVC SAFE?}

High dose IVC has been used for many decades by complementary and alternative medicine providers and physicians, with 
TABLE 2 | Effects of chemotherapeutic agents on plasma vitamin C levels in oncology patients.

\begin{tabular}{|c|c|c|c|}
\hline Study types & Study cohorts & Vitamin $\mathrm{C}$ patients. levels & Reference \\
\hline Single arm & $\begin{array}{l}34 \text { patients with cancer (osteosarcoma, testicular) + cisplatin } \\
\text { combinations }\end{array}$ & $\begin{array}{l}\text { Before chemo: } 46 \mu \mathrm{mol} / \mathrm{L} \\
\text { After chemo: } 33 \mu \mathrm{mol} / \mathrm{L}^{* *}\end{array}$ & Weijl et al., 1998 \\
\hline Single arm & 15 patients with cancer (melanoma, colon, kidney) + interleukin-2 & $\begin{array}{l}\text { Before chemo: } 36 \mu \mathrm{mol} / \mathrm{L} \\
\text { After chemo: } 7 \mu \mathrm{mol} / \mathrm{L}^{* * *}\end{array}$ & Marcus et al., 1991 \\
\hline Single arm & $\begin{array}{l}24 \text { patients with hematopoietic cancers (bone marrow transplant) + } \\
\text { chemotherapy }\end{array}$ & $\begin{array}{l}\text { Before chemo: } 48 \mu \mathrm{mol} / \mathrm{L} \\
\text { After chemo: } 49 \mu \mathrm{mol} / \mathrm{L}\end{array}$ & Jonas et al., 2000 \\
\hline Single arm & $\begin{array}{l}20 \text { patients with hematopoietic cancers (bone marrow transplant) }+ \\
\text { chemotherapy and/or total body irradiation }\end{array}$ & $\begin{array}{l}\text { Before: } 34 \text { or } 43 \mu \mathrm{mol} / \mathrm{L} \\
\text { After: } 14 \text { or } 15 \mu \mathrm{mol} / \mathrm{L}^{* *}\end{array}$ & Hunnisett et al., 1995 \\
\hline Single arm & $\begin{array}{l}15 \text { patients with hematopoietic cancers (stem cell transplantation) + } \\
\text { conditioning regimens }\end{array}$ & $\begin{array}{l}\text { Before chemo: } 37 \mu \mathrm{mol} / \mathrm{L} \\
\text { After chemo: } 22 \mu \mathrm{mol} / \mathrm{L}^{\#} \\
\text { At day 14: } 12 \mu \mathrm{mol} / \mathrm{L}^{\#}\end{array}$ & Nannya et al., 2014 \\
\hline Single arm & $\begin{array}{l}15 \text { patients with hematopoietic cancers (stem cell transplantation) + } \\
\text { conditioning regimens }\end{array}$ & $\begin{array}{l}\text { Before chemo: } 41 \mu \mathrm{mol} / \mathrm{L} \\
\text { After chemo: } 27 \mu \mathrm{mol} / \mathrm{L}^{*} \\
\text { At day } 14: 22 \mu \mathrm{mol} / \mathrm{L}^{*} \\
\text { At day } 30: 34 \mu \mathrm{mol} / \mathrm{L}\end{array}$ & Rasheed et al., 2017 \\
\hline Case control & $\begin{array}{l}30 \text { patients with multiple myeloma before treatment } \\
30 \text { patients with multiple myeloma } 1 \text { month after chemotherapy }\end{array}$ & $\begin{array}{l}\text { Before chemo: } 39 \mu \mathrm{mol} / \mathrm{L} \\
\text { After } 1 \text { month: } 42 \mu \mathrm{mol} / \mathrm{L}^{*}\end{array}$ & Mehdi et al., 2013 \\
\hline
\end{tabular}

${ }^{*} P<0.05 ;{ }^{* *} P<0.001 ;{ }^{* * *} P<0.0001$, $P$-value not reported.

TABLE 3 | Pharmacokinetics of high dose vitamin C in preclinical cancer models and oncology patients with and without chemotherapy.

\begin{tabular}{|c|c|c|c|c|c|}
\hline Model/Cancer & $\begin{array}{l}\text { IVC dose } \\
(\mathrm{g} / \mathrm{kg})^{\mathrm{a}}\end{array}$ & $C_{\max }(\mathrm{mM})$ & AUC $\left(\mathrm{mM}^{*} \mathrm{~h}\right)$ & $t_{1 / 2}(h)$ & Reference \\
\hline \multicolumn{6}{|l|}{ Preclinical studies } \\
\hline $\begin{array}{l}\text { Gulo }^{-/-} \text {mice, } \\
\text { Lewis lung (LL/2) }\end{array}$ & $1.0(\mathrm{IV})$ & 5 & 5 & 1.3 & Campbell et al., 2016b \\
\hline $\begin{array}{l}\text { Nude mice, } \\
\text { hepatoma (TLT) }\end{array}$ & $\begin{array}{l}1.0(\mathrm{IP}) \\
1.0(\mathrm{IV})\end{array}$ & $\begin{array}{c}7 \\
22\end{array}$ & $\begin{array}{l}12 \\
20\end{array}$ & $\begin{array}{l}1.0 \\
0.7\end{array}$ & Verrax and Calderon, 2009 \\
\hline $\begin{array}{l}\text { Wistar rats, } \\
\text { no tumors }\end{array}$ & $\begin{array}{l}0.5(\mathrm{IP}) \\
0.5(\mathrm{IV})\end{array}$ & $\begin{array}{l}3 \\
8\end{array}$ & $\begin{array}{l}- \\
-\end{array}$ & $\begin{array}{l}- \\
-\end{array}$ & Chen et al., 2007 \\
\hline \multicolumn{6}{|l|}{ Without chemotherapy } \\
\hline 12 advanced cancer & 0.6 & 14 & - & - & Hoffer et al., 2015 \\
\hline 10 prostate cancer & $\begin{array}{l}0.07-0.7 \\
(5-60 \mathrm{~g} / \mathrm{d})\end{array}$ & $2-20$ & $4-48$ & $1.7-2.0$ & Nielsen et al., 2015 \\
\hline 15 advanced cancer & $\begin{array}{l}0.8-3.0 \\
\left(30-110 \mathrm{~g} / \mathrm{m}^{2}\right)\end{array}$ & $23-37$ & $74-217$ & $2.1-2.5$ & Stephenson et al., 2013 \\
\hline 11 advanced cancer & $0.1-1.5$ & $2.4-26$ & $6-93^{b}$ & - & Hoffer et al., 2008 \\
\hline \multicolumn{6}{|l|}{ With chemotherapy } \\
\hline 12 advanced cancer with chemotherapy & 0.6 & 14 & - & - & Hoffer et al., 2015 \\
\hline 9 pancreatic cancer with gemcitabine & $\begin{array}{l}0.2-1.8 \\
(15-125 \mathrm{~g} / \mathrm{d})\end{array}$ & $5-30$ & - & - & Welsh et al., 2013 \\
\hline 25 ovarian cancer with carboplatin, paclitaxel & $\begin{array}{l}1.1-1.4 \\
(75-100 \mathrm{~g} / \mathrm{d})\end{array}$ & $20-23$ & - & - & Ma et al., 2014 \\
\hline 14 pancreatic cancer with gemcitabine, erlotinib & $\begin{array}{l}1.1-1.4 \\
(75-100 \mathrm{~g} / \mathrm{d})\end{array}$ & $20-30$ & - & - & Monti et al., 2012 \\
\hline
\end{tabular}

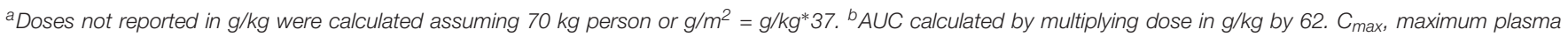
concentration; $t_{1 / 2}$, half-life; $A \cup C$, area under the concentration time curve; $N$, intravenous; IP, intraperitoneal.

few side effects reported (Padayatty et al., 2010). Of 9,328 patients surveyed, only $1 \%$ reported minor side effects that included lethargy, fatigue, change in mental status and vein irritation. More recent Phase 1 safety trials of high dose IVC indicate only minor side effects and no adverse events over and above what would be expected from the underlying disease or chemotherapy side effects (Hoffer et al., 2008; Monti et al., 2012; Stephenson et al., 2013; Welsh et al., 2013).
A minor product of vitamin C metabolism is oxalate which has the potential to form calcium oxalate crystals in individuals predisposed to renal stone formation. One patient with a history of renal calculi developed a kidney stone following 2 weeks of continuous IVC infusion (Riordan et al., 2005). Acute oxalate nephropathy has also been reported in several cases following high dose IVC administration, however, the patients all exhibited existing renal dysfunction (Lawton et al., 1985; Wong et al., 1994; 
Cossey et al., 2013). Therefore, high dose IVC is contraindicated for patients with renal dysfunction due to the inability of the kidneys to clear high circulating concentrations. However, in individuals with normal renal function, IVC infusions of up to $1.5 \mathrm{~g} / \mathrm{kg}$ body weight resulted in less than $0.5 \%$ conversion into oxalic acid (Robitaille et al., 2009).

Glucose-6-phosphate dehydrogenase (G6PD) deficiency is typically screened for prior to high dose IVC administration, due to two case reports of hemolytic anemia in G6PD deficient individuals following $80 \mathrm{~g}$ IVC administration (Rees et al., 1993; Quinn et al., 2017). The lower IVC doses typically used for quality of life improvement (e.g., $\leq 10 \mathrm{~g} / \mathrm{d}$ ) would be unlikely to precipitate hemolytic anemia in G6PD deficient individuals due to lack of in vivo hydrogen peroxide generation at these doses.

Intravenous vitamin $\mathrm{C}$ has been shown to interfere with many point-of-care glucose meters, even at low gram doses (Tang et al., 2000). IVC can cause either false positive or false negative results depending on the biochemistry utilized in the monitor, therefore, caution is required for patients needing regular glucose monitoring. However, IVC does not interfere with laboratory-based glucose tests which utilize absorbance photometric rather than electrochemical detection (Tang et al., 2000; Kahn and Lentz, 2015). Some clinicians have used the detection of IVC by point-of-care glucose monitors as a convenient method for determining peak plasma vitamin $\mathrm{C}$ concentrations in patients receiving IVC infusions (Ma et al., 2013).

\section{Q4. DOES IVC INTERFERE WITH CHEMOTHERAPY OR RADIOTHERAPY?}

Potential interactions between vitamin $\mathrm{C}$ and chemotherapeutic agents have long been a matter of debate (D'Andrea, 2005; Simone et al., 2007; Lawenda et al., 2008; Verrax and Calderon, 2008). Because of vitamin C's potent antioxidant activity, many clinicians believe they have to avoid the concurrent use of IVC during all chemotherapy regimens. However, different chemotherapeutic agents act via different mechanisms, and only some act via oxidative mechanisms (Simone et al., 2007). Nevertheless, it has been recommended for administered natural therapies to allow five half-lives to elapse prior to administration of chemotherapeutic agents to eliminate potential interactions (Seely et al., 2007). Because vitamin C has a relatively short half-life of $<2 \mathrm{~h}$ in circulation due to rapid renal clearance, IVC is typically administered the day before or after chemotherapy administration (Stephenson et al., 2013; Nielsen et al., 2015). However, if the chemotherapeutic agent does not act via oxidative mechanisms, then concurrent IVC administration may not be an issue and would be more patient centered.

Animal studies have indicated that concurrent administration of vitamin $\mathrm{C}$ to numerous different chemotherapeutic agents (e.g., gemcitabine, paclitaxel, carboplatin, melphalan, carfilzomib, bortezomib, cisplatin, and temozolomide) synergistically decreased xenograft tumor growth, including in a chemotherapy resistant pancreatic tumor model, and synergistically increased survival (Table 4) (Espey et al., 2011; Ma et al., 2014; Wang C. et al., 2017; Xia et al., 2017). No difference in the antitumor activity of the chemotherapeutic agents dacarbazine and valproic acid was observed when combined with high dose parenteral vitamin $\mathrm{C}$ in a murine melanoma model (Serrano et al., 2015). Administration of vitamin C to mice and guinea pigs reduced the toxic side effects of paclitaxel and doxorubicin without interfering with their antitumor effects (Fujita et al., 1982; Park et al., 2012). Interestingly, many of the pre-clinical studies showed that administration of IVC alone was as effective at decreasing tumor growth and promoting survival as the chemotherapeutic agents themselves (Table 4).

Human trials have shown no adverse effects from combining IVC with a number of different chemotherapeutic agents (e.g., carboplatin, paclitaxel, decitabine, cytarabine, aclarubicin, gemcitabine, erlotinib, and temozolomide; Table 5), and in many cases decreased off-target toxicity and improved healthrelated quality of life were observed (Welsh et al., 2013; Kawada et al., 2014; Ma et al., 2014; Hoffer et al., 2015; Polireddy et al., 2017; Zhao et al., 2018). Vitamin C is routinely administered in combination with arsenic trioxide to enhance its efficacy in the treatment of refractory multiple myeloma (Fritz et al., 2014). Although co-administration of high dose thiol antioxidants, such as glutathione and $N$-acetyl cysteine, was contraindicated in animal models (Chen et al., 2011; Yun et al., 2015), normal supplemental intakes of these antioxidants (e.g., 1-1.5 g/d) by patients would be unlikely to interact with high dose IVC treatments (Padayatty et al., 2006).

Radiotherapy with ionizing radiation generates free radicals and also increases levels of catalytic transition metal ions in tissues (Cieslak and Cullen, 2015). Cell culture studies have shown radio-sensitizing effects of high dose vitamin $\mathrm{C}$ in combination with ionizing irradiation (Shinozaki et al., 2011; Herst et al., 2012; Hosokawa et al., 2015). Only a few studies have been carried out in animal models, with most showing radio-sensitizing effects of vitamin $\mathrm{C}$ (Du et al., 2015; Cieslak et al., 2016), although one model showed radioprotective effects (Grasso et al., 2014). These differences likely reflect the timing of the radiation treatment relative to vitamin $\mathrm{C}$ administration. For example, in the Grasso et al. (2014) study, radiation treatment was carried out only $2 \mathrm{~h}$ after intraperitoneal administration of vitamin $\mathrm{C}$, while in the other studies radiation treatment was carried out on days 3 or 5 following initiation of high dose vitamin C administration (Du et al., 2015; Cieslak et al., 2016). In these latter studies, high dose vitamin $\mathrm{C}$ administration was shown to act synergistically with radiotherapy, decreasing tumor growth and enhancing survival (Cieslak and Cullen, 2015; Cieslak et al., 2016). PET imaging showed tumoristatic activity of vitamin $\mathrm{C}$ administration alone and radiation therapy alone, however, the two combined showed tumoricidal activity (Cieslak et al., 2016). Addition of vitamin C to radiotherapy and chemotherapy combinations further improved anti-tumor activity and survival (Cieslak and Cullen, 2015; Schoenfeld et al., 2017). Clearly, more studies 


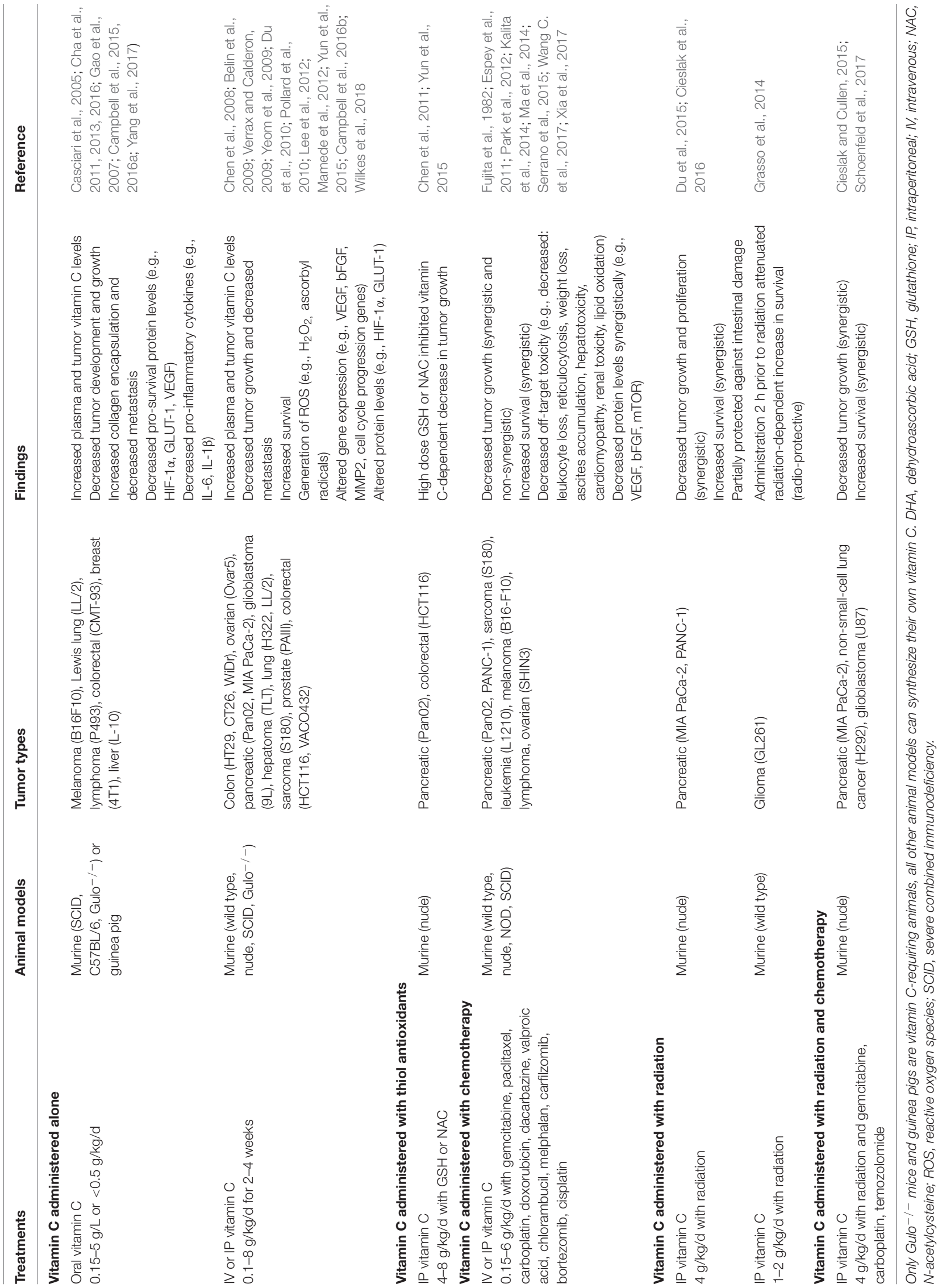




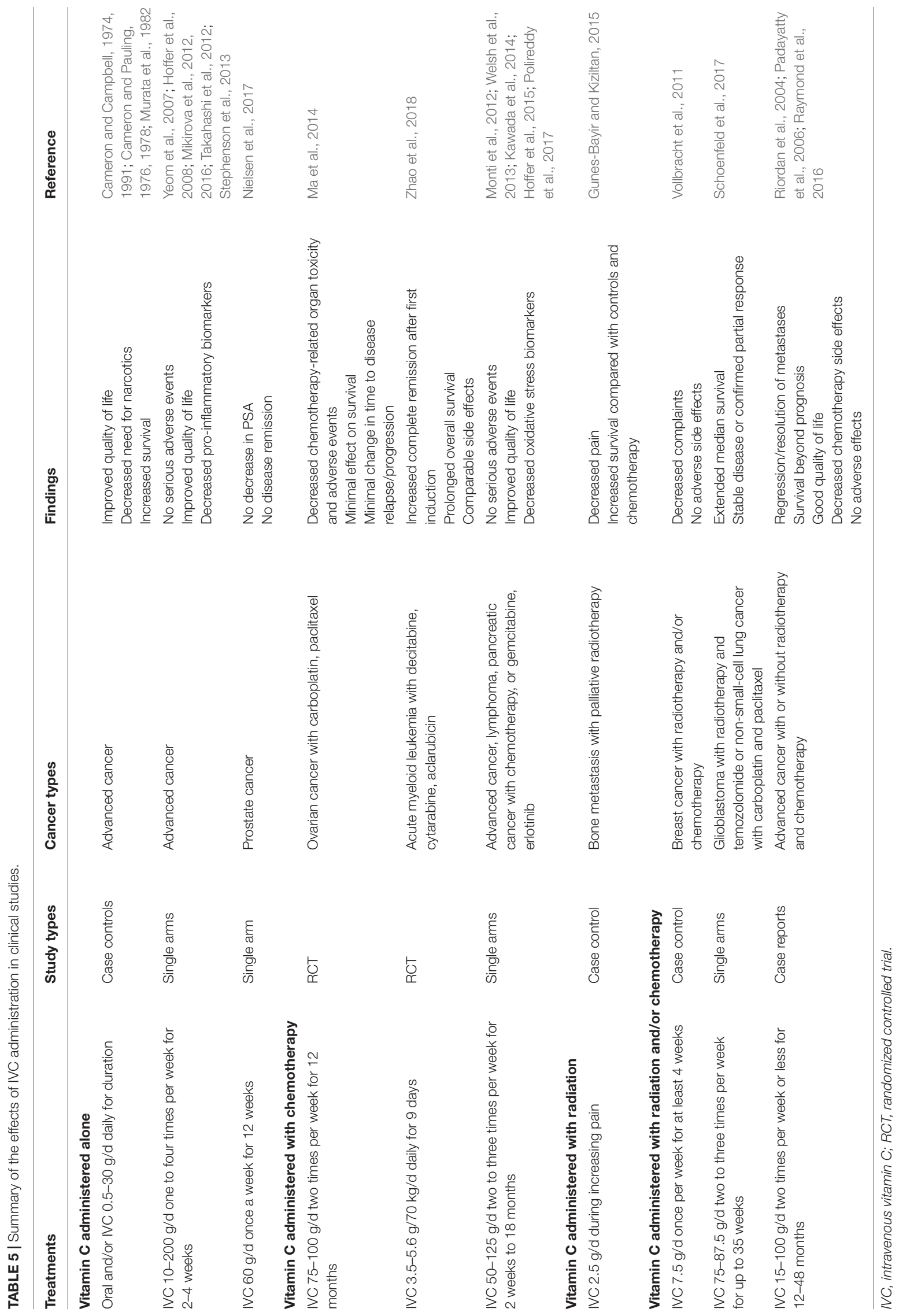


need to be carried out to determine appropriate tumor models and optimal timing and dosing of IVC combined with radiotherapy.

\section{Q5. DOES IVC DECREASE THE TOXIC SIDE EFFECTS OF CHEMOTHERAPY AND IMPROVE QUALITY OF LIFE?}

Numerous animal studies have shown decreased off-target toxicity of chemotherapeutic agents following administration of oral and IVC (Table 4). Vitamin C administration decreased white blood cell loss, weight loss, ascites accumulation, hepatotoxicity, reticulocytosis, lipid oxidation, and cardiomyopathy induced by the chemotherapeutic agents. In a murine ovarian cancer model, a synergistic decrease in ascites accumulation was observed with high dose vitamin C administration in combination with carboplatin and paclitaxel (Ma et al., 2014). Administration of vitamin C also decreased the toxic side effects of doxorubicin and paclitaxel, as well as cisplatin, which is known to cause off-target oxidative stress (Fujita et al., 1982; Park et al., 2012; Chen et al., 2014). It has been noted that combination therapy with vitamin $\mathrm{C}$ enhances sensitivity to specific anti-cancer drugs, thus potentially decreasing the required dosage and ameliorating associated side-effects (Cimmino et al., 2017; Wang G. et al., 2017). Low dose IVC (e.g., 1 g/infusion) is often administered with arsenic trioxide for multiple myeloma or leukemia to improve tolerability of the chemotherapeutic agent (Fritz et al., 2014).

Decreased chemotherapy-related toxicity has been demonstrated in patients with stage III-IV ovarian cancer receiving chemotherapy (carboplatin and paclitaxel) in conjunction with high-dose IVC (75-100 g two times per week) (Ma et al., 2014). Adverse events were evaluated and grade 1 and 2 toxicities were found to be significantly decreased in the group receiving IVC. Decreased toxicities were observed in almost all the evaluated organ systems, e.g., neurological, bone marrow, hepatobiliary/pancreatic, renal/genitourinary, infection, pulmonary, gastrointestinal, and dermatological. Interestingly, despite decreasing chemotherapy-related toxicity, IVC did not appear to adversely affect the anti-cancer activity of the drugs as assessed by survival of the patients or time to disease relapse or progression (Ma et al., 2014). In support of a role for vitamin $\mathrm{C}$ in decreasing chemotherapy-related toxicity, a Phase I clinical study of patients with pancreatic cancer treated with gemcitabine reported decreased plasma $\mathrm{F}_{2}$-isoprostanes, an established oxidative stress biomarker, following administration of high dose IVC (Welsh et al., 2013). Thus, IVC is a potentially useful adjunctive therapy to decrease off-target toxicity of chemotherapeutic agents and as a result may also improve the health-related quality of life of oncology patients (Carr et al., 2014; Carr and McCall, 2017).

Since the early 1970s and 1980s, clinicians have reported improved subjective quality of life in patients following administration of both high dose oral and IVC (Cameron and Campbell, 1974; Murata et al., 1982). More recent studies specifically assessing the effects of IVC administration on cancer- and chemotherapy-related quality of life using validated questionnaires have shown decreases in common symptoms, such as fatigue, pain, nausea/vomiting, insomnia and appetite loss, following administration of IVC (Yeom et al., 2007; Takahashi et al., 2012; Stephenson et al., 2013). These studies also demonstrated improvements in overall health and, specifically, enhanced physical, emotional, cognitive, and social functioning. Interestingly, even relatively low IVC doses of 2.5-10 g/infusion provided decreased symptoms and improved quality of life (Yeom et al., 2007; Vollbracht et al., 2011; Kiziltan et al., 2014; Gunes-Bayir and Kiziltan, 2015), suggesting that antioxidant/anti-inflammatory functions and/or enzyme cofactor mechanisms of vitamin $\mathrm{C}$ may be involved in the quality of life improvements (Carr et al., 2014; Carr and McCall, 2017).

\section{Q6. WHAT ARE THE RELEVANT MECHANISMS OF ACTION OF IVC?}

\section{Generation of Hydrogen Peroxide}

Currently, one of the most widely accepted anti-cancer mechanisms proposed for vitamin $\mathrm{C}$ is based on its so-called 'prooxidant' activity (Parrow et al., 2013). However, this terminology can be misleading as vitamin $\mathrm{C}$ itself always acts as antioxidant, through donation of electrons; the 'pro-oxidant' action occurs subsequently and is therefore an indirect effect. As such, the term 'pro-drug' has been adopted by some researchers (Chen et al., 2005). In vitro, vitamin $C$ (in the form of the ascorbate anion) is able to reduce transition metal ions, such as ferric and cupric cations, which are present in buffers or in cell culture media. The reduced transition metal ions are then able to generate hydrogen peroxide through reduction of oxygen to the superoxide radical, which can react with itself to form hydrogen peroxide. However, whether catalytically available transition metal ions are found in vivo and can cause enhanced oxidative stress is still a matter of some debate since iron and copper are normally sequestered in transport and storage proteins such as transferrin, ferritin and ceruloplasmin (Carr and Frei, 1999a). Nevertheless, in some pathological situations, such as iron and copper-overload diseases and during tissue injury, free transition metal ions may become more catalytically available (Du et al., 2012). It has also been postulated that transition metal ions are catalytically more available in the extracellular fluid of the tumor microenvironment (Chen et al., 2005).

In vitro studies have shown that addition of high (millimolar) concentrations of vitamin $\mathrm{C}$ to cell culture media exhibits differential cytotoxicity toward various cancer cell lines, but not toward normal cultured cells (Chen et al., 2005, 2008). This cytotoxic effect appears to be primarily due to generation of hydrogen peroxide (Figure 1), as evidenced by protection via exogenously added catalase (Sestili et al., 1996; Clement et al., 2001). The differential sensitivity of cancer cell lines to vitamin C-generated hydrogen peroxide may reflect their endogenous catalase content (Doskey et al., 2016). Recently, generation of dehydroascorbic acid from vitamin $\mathrm{C}$ added to culture media and subsequent uptake of the dehydroascorbic acid 


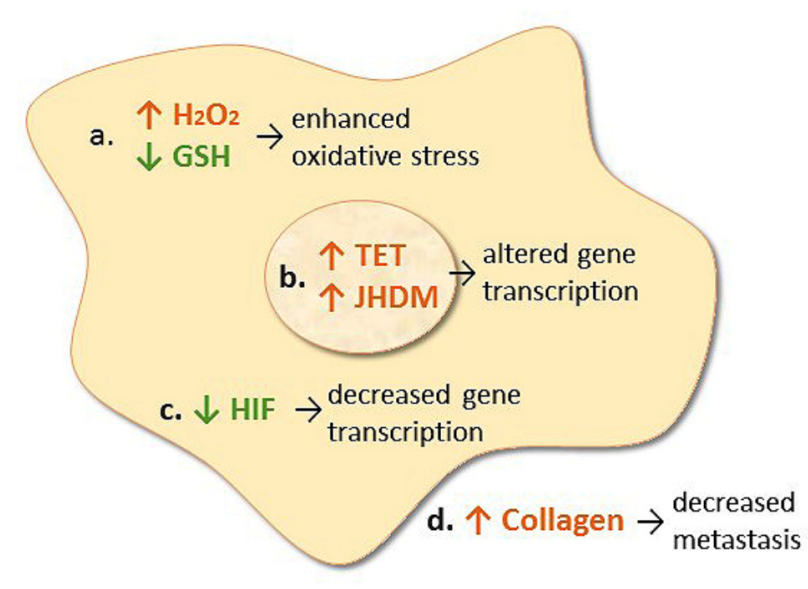

FIGURE 1 | Proposed mechanisms of action of intravenous vitamin C in cancer cells. (a) Transition metal ion-dependent generation of hydrogen peroxide $\left(\mathrm{H}_{2} \mathrm{O}_{2}\right)$ and oxidation of intracellular glutathione $(\mathrm{GSH})$ which causes enhanced oxidative stress and potential cell death. (b) Enhances ten-eleven translocation (TET) DNA hydroxylase activity and jumonji histone demethylase (JHDM) activity which alters gene transcription. (c) Decreases HIF protein levels which decreases gene transcription. (d) Increases collagen synthesis resulting in decreased tumor invasion and metastasis.

into colorectal cancer cells overexpressing glucose transporter 1 was proposed to increase intracellular oxidative stress through oxidation of glutathione (Yun et al., 2015). However, because catalase was not added to the cell cultures, generation of hydrogen peroxide and subsequent oxidative stress due to this reactive oxygen species, rather than dehydroascorbic acid, cannot be ruled out. Furthermore, recent research has shown that addition of vitamin $\mathrm{C}$ is more effective than comparable concentrations of enzymatically generated hydrogen peroxide, and addition of noncytotoxic concentrations of vitamin $\mathrm{C}$ with hydrogen peroxide exhibits synergistic effects (Rouleau et al., 2016). This indicates that additional vitamin-dependent anti-tumor mechanisms are occurring.

Pharmacokinetic studies in oncology patients have provided insight into the doses of IVC required to generate high (millimolar) concentrations of vitamin C in plasma (Table 3) (Hoffer et al., 2008; Stephenson et al., 2013; Welsh et al., 2013; Nielsen et al., 2015). It is generally believed that plasma vitamin C concentrations $>20 \mathrm{mmol} / \mathrm{L}$ are required for hydrogen peroxide generation in vivo (Chen et al., 2008). However, it should be noted that hydrogen peroxide generated in the circulation will be rapidly detoxified by antioxidant enzymes present in erythrocytes, including catalase, glutathione peroxidase, and peroxiredoxin-2 (Guemouri et al., 1991; Low et al., 2008). Thus, erythrocytes will act as a sink for hydrogen peroxide generated in the circulation (Zhang et al., 2016). This premise has been confirmed in animal studies whereby low concentrations of hydrogen peroxide were detected in extracellular fluid, but not in blood, following administration of high dose parenteral vitamin C (Chen et al., 2007, 2008).

Administration of high dose parenteral vitamin C (i.e., 1$8 \mathrm{~g} / \mathrm{kg} / \mathrm{d}$ ) to murine models has been shown to decrease tumor growth and enhance survival (Table 4) (Du et al., 2012; Campbell and Dachs, 2014). The 'pro-oxidant' activity of vitamin C is thought to predominate at these higher doses as low levels of hydrogen peroxide and the ascorbyl radical intermediate were detected in the extracellular fluid of rodent models (Chen et al., 2007, 2008). Furthermore, co-administration of high dose thiol antioxidants such as glutathione and $\mathrm{N}$-acetyl cysteine inhibited the anti-tumor effect of high-dose vitamin $\mathrm{C}$ administration (Chen et al., 2011; Yun et al., 2015). As such, in animal models administered very high dose vitamin $\mathrm{C}$, there is some evidence to suggest that a 'pro-oxidant' mechanism is occurring. However, it should be noted that the doses of vitamin $\mathrm{C}$ administered to animal models are typically four to eight times higher and more frequent (daily vs. twice a week) than those administered to patients. It should also be noted that most of the animal models used (other than Gulo knockout mice and guinea pigs) can also synthesize their own vitamin C. As yet, there is little evidence to indicate that the proposed 'pro-oxidant' mechanism is occurring in oncology patients administered IVC (Welsh et al., 2013).

\section{Enzyme Cofactor Activities}

Animal studies, particularly in vitamin C-requiring animals such as Gulo knockout mice and guinea pigs, have indicated that oral dosing (e.g., 0.3-5 g/L) (Casciari et al., 2005; Gao et al., 2007; Campbell et al., 2015, 2016a; Yang et al., 2017) and low parenteral doses of vitamin C (e.g., $0.1 \mathrm{~g} / \mathrm{kg} / \mathrm{d}$ ) (Belin et al., 2009) exhibit comparable decreases in tumor growth to high dose parenteral vitamin C (i.e., 1-8 g/kg/d; Table 4). Since hydrogen peroxide is not detected following oral or low dose IVC administration (Chen et al., 2007), this suggests possible tumor growth inhibition mechanisms other than hydrogen peroxide generation are likely operating in these situations. Numerous cell culture and preclinical studies have shown regulatory effects of vitamin $\mathrm{C}$ administration on various transcription factors and cell signaling pathways, with subsequent effects on cell cycle, angiogenesis, and cell death pathways (Parrow et al., 2013). Analysis of tissues from various animal models has indicated regulation of numerous genes and their products following administration of vitamin C (Gao et al., 2007; Belin et al., 2009; Park et al., 2009; Yeom et al., 2009; Lee et al., 2012; Ma et al., 2014; Campbell et al., 2015, 2016a,b). Thus, it appears that vitamin $\mathrm{C}$ administration, particularly at lower doses, has gene-regulatory effects.

Vitamin C is a cofactor for a family of metalloenzymes with pleotropic biosynthetic and gene regulatory roles (Du et al., 2012). It has long been known to be a cofactor for the three hydroxylase enzymes essential for the stabilization of collagen tertiary structure (Englard and Seifter, 1986). Research has shown increased collagen encapsulation of tumors in Gulo knockout mice with melanoma and breast tumors following supplementation with low dose oral vitamin C $(0.15 \mathrm{~g} / \mathrm{L}$, Figure 1) (Cha et al., 2011, 2013). Decreased metastases were also observed in these models. This work has been confirmed recently in a pancreatic cancer model (Polireddy et al., 2017). Increased levels of collagen were detected in tumor stroma of vitamin C-treated mice and this was associated with decreased tumor invasion. Resected tumors from pancreatic cancer patients treated with IVC also exhibited increased collagen content 
(Polireddy et al., 2017). Since enhanced collagen mRNA levels were also observed in the tumors from vitamin C-treated mice, this suggests that gene regulatory mechanisms are also involved.

In the early 2000s, vitamin C was demonstrated to regulate the transcription factor hypoxia inducible factor- $1 \alpha$ (HIF1 $\alpha$ ) (Hirsila et al., 2003; Koivunen et al., 2004; Hirota and Semenza, 2005). HIF-1 $\alpha$ is a constitutively expressed transcription factor which regulates numerous pro-survival genes. Under normoxic conditions, HIF- $1 \alpha$ is downregulated via hydroxylase-mediated modifications which prevents coactivator binding and targets HIF for proteosomal degradation. In the hypoxic core of solid tumors HIF-1 $\alpha$ is upregulated due to the absence of substrates and cofactors required for hydroxylasedependent downregulation. Vitamin $C$ is a cofactor for the HIF hydroxylases (Kuiper and Vissers, 2014). Animal studies have shown downregulation of HIF-1 $\alpha$ and downstream prosurvival proteins (e.g., glucose transporter 1, vascular epithelial growth factor, and carbonic anhydrase) following administration of oral or parenteral vitamin C (Figure 1) (Campbell et al., 2015, 2016a,b). In human colorectal tumors and other tumors there was an inverse association between tumor vitamin $C$ levels and expression of HIF and related downstream proteins (Kuiper et al., 2010, 2014a; Jozwiak et al., 2017), and enhanced disease-free survival was observed in patients who had higher vitamin $\mathrm{C}$ levels in their tumors (Kuiper et al., 2014a).

Recent research has uncovered a role for vitamin $\mathrm{C}$ in epigenetic regulation via acting as a cofactor for DNA and histone demethylases which belong to the same family of enzymes as the collagen and HIF hydroxylases (Camarena and Wang, 2016; Gillberg et al., 2017). Vitamin C acts as a cofactor for the ten-eleven translocation (TET) dioxygenases which hydroxylate methylated cytosine moieties in DNA (Blaschke et al., 2013; Minor et al., 2013; Yin et al., 2013). The hydroxymethylcytosine mark can be further oxidized and subsequently removed through both active and passive DNA repair mechanisms, but may also represent an epigenetic mark in its own right (Camarena and Wang, 2016). It is noteworthy that a decrease in DNA hydroxymethylation has been observed in cancer cells and tumors (Haffner et al., 2011; Kudo et al., 2012; Lian et al., 2012; Kroeze et al., 2015). Recent research has indicated that vitamin $\mathrm{C}$ can modulate the epigenome of leukemia cells and regulate hematopoietic stem cell function in a TET-dependent fashion, suppressing leukemia progression in pre-clinical models (Figure 1) (Agathocleous et al., 2017; Cimmino et al., 2017; Mingay et al., 2017; Zhao et al., 2018). Research has also indicated that vitamin $\mathrm{C}$ treatment increases hydroxymethylation in lymphoma and melanoma cells, and causes a decrease in tumor-cell invasiveness and clonogenic growth (Gustafson et al., 2015; Shenoy et al., 2017). Thus, epigenetic mechanisms may be involved in the attenuated metastasis that has been observed in animal models and patients following administration of vitamin C (Padayatty et al., 2006; Pollard et al., 2010; Cha et al., 2013; Polireddy et al., 2017).

Vitamin $\mathrm{C}$ is also a cofactor for several Jumonji C domaincontaining histone demethylases (JHDM) that catalyze histone demethylation (Camarena and Wang, 2016). Methylation of lysine and arginine residues on histones is closely associated with activation or silencing of transcription. JHDM can demethylate mono-, di-, and trimethylated histone lysine and arginine residues (Klose et al., 2006). Vitamin C is required for optimal catalytic activity and demethylation by JHDM (Tsukada et al., 2006). The involvement of vitamin C in JHDMdependent histone demethylation was confirmed in somatic cell reprogramming and T-cell maturation (Wang et al., 2011; Manning et al., 2013; Ebata et al., 2017). Thus, it appears that vitamin $\mathrm{C}$ can regulate the epigenome via acting as a cofactor for both DNA and histone demethylases. Due to the multitude of genes regulated through both DNA and histone demethylation, it is likely that epigenomic regulation by vitamin $\mathrm{C}$ may play a major role in its pleiotropic health promoting and disease modifying effects. Continuing research in this field will no doubt reveal exciting insights and treatment possibilities.

\section{Antioxidant and Anti-inflammatory Activities}

It has been suggested that oxidative stress, chronic inflammation, and cancer are closely linked (Reuter et al., 2010). Oxidative stress can activate a variety of transcription factors, leading to the expression of hundreds of different genes, including those of proinflammatory cytokines. Vitamin $\mathrm{C}$ is a potent antioxidant both in plasma and within cells due to its ability to scavenge a wide range of reactive oxygen species, thereby protecting important biomolecules from oxidative damage (Carr and Frei, 1999a). Patients with cancer tend to have elevated markers of oxidative stress, such as malondialdehyde (Hunnisett et al., 1995; Torun et al., 1995; Mahdavi et al., 2009; Sharma et al., 2009; Mehdi et al., 2013). An early study in healthy volunteers administered low dose IVC showed a decrease in lipid oxidation biomarkers (Muhlhofer et al., 2004). More recently, administration of high dose IVC to patients with pancreatic cancer produced a decrease in $\mathrm{F}_{2}$-isoprostanes, a marker of systemic oxidative stress (Welsh et al., 2013), suggesting a systemic antioxidant effect of IVC. Detection of ascorbyl radicals in the blood and extracellular fluid of animal models has been used as evidence for a 'pro-oxidant' role for vitamin $\mathrm{C}$, i.e., they are an intermediate in the reduction of transition metal ions (Chen et al., 2007, 2008). Although very low (nanomolar) levels of ascorbyl radical were detected in the circulation of patients in the human intervention study (Welsh et al., 2013), these radicals can also be formed through vitamin C's oxidant scavenging function (Carr and Frei, 1999a). Thus, detection of low level ascorbyl radicals, which parallels ascorbate concentrations, could instead be indicative of oxidant scavenging, i.e., an antioxidant, role of vitamin C (Muhlhofer et al., 2004).

Elevated markers of inflammation, such as C-reactive protein and various cytokines, have been reported in oncology patients (Mayland et al., 2005; Mikirova et al., 2012, 2013, 2016; Nannya et al., 2014). Vitamin C exhibits anti-inflammatory functions via modulating cytokine levels (Carr and Maggini, 2017) and animal models of melanoma and breast cancer have indicated decreased pro-inflammatory cytokine (interleukin-6, interleukin-1) levels following vitamin C administration (Cha et al., 2011, 2013). In patients with various cancers, administration of $25-50 \mathrm{~g}$ IVC 
decreased a number of different inflammatory mediators (such as C-reactive protein) and pro-inflammatory cytokines (Mikirova et al., 2012, 2016). Because oxidants can enhance inflammation, it is not clear if the cytokine-modulatory effects of vitamin C are due to its oxidant scavenging function or its gene regulatory cofactor functions (Song et al., 2017). It is noteworthy that patients with higher levels of inflammation also appear to have a higher requirement for vitamin C (Mikirova et al., 2013).

\section{Q7. WHAT ARE THE OPTIMAL DOSES, FREQUENCY, AND DURATION OF IVC THERAPY?}

Intravenous vitamin $\mathrm{C}$ has been used for decades by health care professionals with very little consistency in the dose, frequency, or duration of use. A survey of complementary and alternative medicine practitioners showed an average dose of $28 \mathrm{~g} /$ infusion (range of 1-200 g/infusion), a frequency of approximately twice a week (range of 1-7 times per week), and about 19 treatments per patient (range of 1-80 treatments) (Padayatty et al., 2010). Because of the prevailing 'pro-oxidant' paradigm of IVC, it is generally believed that 'more is better' and doses as high as $200 \mathrm{~g}$ /infusion have been administered to oncology patients (Table 5) (Padayatty et al., 2010; Stephenson et al., 2013). Lower IVC doses of 2.5-10 g/infusion have been shown to decrease common cancer- and chemotherapy-related symptoms and improve health-related quality of life (Carr et al., 2014).

Although the 'pro-oxidant' activity of IVC has yet to be conclusively demonstrated in humans, there may be alternate rationales for administering high dose IVC. Solid tumors exhibit dysregulated blood supply which limits diffusion of oxygen and other nutrients to the core of the tumors. Utilizing a well-established multicell-layered, three-dimensional pharmacokinetic model, Kuiper et al. (2014b) measured vitamin $\mathrm{C}$ diffusion and transport parameters through dense tissue. The investigators demonstrated that supra-physiological plasma concentrations (i.e., up to $500 \mu \mathrm{mol} / \mathrm{L}$ ) were required to achieve effective delivery of vitamin $\mathrm{C}$ to poorly vascularized tumor tissue. Enhanced delivery of vitamin $\mathrm{C}$ to the hypoxic core of solid tumors would facilitate down-regulation of the HIF-driven hypoxic response (Kuiper and Vissers, 2014). The efficacy of IVC against metastatic tumors could also be due, in part, to the generally smaller size of metastases allowing better diffusion of vitamin $\mathrm{C}$ into the tumor, thus facilitating its various generegulatory mechanisms. Uptake of vitamin $\mathrm{C}$ into tumor cells may also be dependent upon vitamin $\mathrm{C}$ transporter (SVCT2) status and polymorphisms, which is an area that warrants further investigation (Wang C. et al., 2017; Wohlrab et al., 2017).

Preclinical studies indicate that a single infusion of vitamin C is not as effective as multiple infusions and a higher frequency of administration appears to be more beneficial (Takemura et al., 2010; Campbell et al., 2016b). For example, daily intraperitoneal injections of vitamin $\mathrm{C}$ slowed tumor growth in the mice and downregulated HIF- $1 \alpha$ and downstream gene products to a greater extent than injections every other day (Campbell et al., 2016b). A trial of castration-resistant prostate cancer patients who were administered only one $60 \mathrm{~g}$ infusion per week did not show diminished PSA levels or disease remission after 12 weeks (Nielsen et al., 2017). However, daily administration of high dose IVC to rodents with implanted prostate tumor cells showed decreased tumor growth and lung metastases (Pollard et al., 2010). Although continuous vitamin C infusion has been piloted (Riordan et al., 2005), this is usually only practical if the patients are hospitalized. However, because IVC solutions are remarkably stable, even at ambient temperature and in the light (Carr et al., 2018), it might be possible to utilize continuous infusion bottles typically used for home intravenous antibiotic administration. However, since intermittent infusions allow for high peak plasma concentrations (de Grooth et al., 2018), there is debate as to whether continuous infusion is better than intermittent infusions over a longer period (Cameron, 1991; Gonzalez et al., 2012). As mentioned above, high peak concentrations may be required to facilitate uptake of vitamin $\mathrm{C}$ into solid tumors.

\section{CONCLUSION}

- Do oncology patients have compromised vitamin C status? Yes, studies consistently show that patients with cancer have lower mean circulating vitamin $\mathrm{C}$ levels than healthy volunteers. These patients also exhibit higher rates of hypovitaminosis $\mathrm{C}$ and deficiency. Furthermore, chemotherapy can impact negatively on the vitamin C status of oncology patients. Because of vitamin C's supportive functions in the body, increasing the vitamin $\mathrm{C}$ status of oncology patients is likely to be of benefit.

- Is IV the optimal route for vitamin $\mathrm{C}$ administration? Yes, IV administration of vitamin $\mathrm{C}$ can provide significantly higher peak plasma concentrations because it bypasses the regulated intestinal uptake of oral vitamin $\mathrm{C}$. These higher concentrations are believed to be required for some of the proposed anti-cancer mechanisms of vitamin $\mathrm{C}$ and may also enhance diffusion of the vitamin into the hypoxic core of solid tumors.

- Is IVC safe? Yes, IVC is remarkably safe, considering the massive (>75 g) doses that are often administered. However, there are several currently known situations where caution is warranted. These include patients with impaired renal function due to their inability to adequately clear high IVC doses from circulation, and patients with G6PD deficiency due to inability to detoxify oxidative stress generated by high dose IVC administration. Caution is also required for patients requiring regular glucose monitoring due to the potential for IVC to interfere with point-of-care glucose monitors.

- Does IVC interfere with chemotherapy or radiotherapy? Clinical trials indicate that IVC does not adversely interfere with chemotherapy and pre-clinical studies indicate that it may in fact act synergistically in combination with different chemotherapeutic agents. There is as yet limited research around interference with radiotherapy, with conflicting results likely due to the timing of the interventions. 
- Does IVC decrease the toxic side effects of chemotherapy and improve quality of life? Both pre-clinical and clinical studies indicate that IVC can decrease the off-target toxicity of chemotherapeutic agents, likely through its antioxidant and anti-inflammatory activities, without affecting the anti-cancer activities of the chemotherapeutic agents. The reduction in specific chemotherapy-related side-effects results in an overall improvement in the health-related quality of life of oncology patients.

- What are the relevant mechanisms of action of IVC? A number of plausible anti-cancer mechanisms have been proposed, such as indirect generation of hydrogen peroxide, enzyme cofactor activities (e.g., collagen synthesis, HIF hypoxic response regulation, TET and JHDM epigenetic regulation), as well as antioxidant and anti-inflammatory functions. Different cancers likely respond differently to IVC therapy depending upon their underlying mechanisms. Thus, future work should focus on tailoring IVC regimens to specific cancers or cancer subtypes, e.g., hematological cancers that are driven specifically by TET mutations may respond more readily to IVC therapy.

- What are the optimal doses, frequency, and duration of IVC therapy? Although these are the most relevant questions clinically, there is still little consensus as to how much, how often and for how long to administer IVC to oncology patients. The different proposed mechanisms

\section{REFERENCES}

Agathocleous, M., Meacham, C. E., Burgess, R. J., Piskounova, E., Zhao, Z., Crane, G. M., et al. (2017). Ascorbate regulates haematopoietic stem cell function and leukaemogenesis. Nature 549, 476-481. doi: 10.1038/nature23876

Alexandrescu, D. T., Dasanu, C. A., and Kauffman, C. L. (2009). Acute scurvy during treatment with interleukin-2. Clin. Exp. Dermatol. 34, 811-814. doi: 10.1111/j.1365-2230.2008.03052.x

Anthony, H. M., and Schorah, C. J. (1982). Severe hypovitaminosis C in lungcancer patients: the utilization of vitamin $\mathrm{C}$ in surgical repair and lymphocyterelated host resistance. Br. J. Cancer 46, 354-367. doi: 10.1038/bjc.1982.211

Belin, S., Kaya, F., Duisit, G., Giacometti, S., Ciccolini, J., and Fontes, M. (2009). Antiproliferative effect of ascorbic acid is associated with the inhibition of genes necessary to cell cycle progression. PLoS One 4:e4409. doi: 10.1371/journal. pone.0004409

Blaschke, K., Ebata, K. T., Karimi, M. M., Zepeda-Martinez, J. A., Goyal, P., Mahapatra, S., et al. (2013). Vitamin C induces Tet-dependent DNA demethylation and a blastocyst-like state in ES cells. Nature 500, 222-226. doi: $10.1038 /$ nature 12362

Block, G., Norkus, E., Hudes, M., Mandel, S., and Helzlsouer, K. (2001). Which plasma antioxidants are most related to fruit and vegetable consumption? Am. J. Epidemiol. 154, 1113-1118. doi: 10.1093/aje/154.12.1113

Camarena, V., and Wang, G. (2016). The epigenetic role of vitamin C in health and disease. Cell Mol. Life Sci. 73, 1645-1658. doi: 10.1007/s00018-016-2145-x

Cameron, E. (1991). Protocol for the use of vitamin C in the treatment of cancer. Med. Hypotheses. 36, 190-194. doi: 10.1016/0306-9877(91)90128-L

Cameron, E., and Campbell, A. (1974). The orthomolecular treatment of cancer. II. Clinical trial of high-dose ascorbic acid supplements in advanced human cancer. Chem. Biol. Interact. 9, 285-315. doi: 10.1016/0009-2797(74)90019-2

Cameron, E., and Campbell, A. (1991). Innovation vs. quality control: an 'unpublishable' clinical trial of supplemental ascorbate in incurable cancer. Med. Hypotheses. 36, 185-189. doi: 10.1016/0306-9877(91)90127-K

Cameron, E., and Pauling, L. (1976). Supplemental ascorbate in the supportive treatment of cancer: prolongation of survival times in terminal human cancer. Proc. Natl. Acad. Sci. U.S.A. 73, 3685-3689. doi: 10.1073/pnas.73.10.3685 of action provide some insight into dosing, with higher doses (>50 g/d) being required for some anti-cancer mechanisms, and lower doses $(\leq 10 \mathrm{~g} / \mathrm{d})$ being sufficient for decreasing symptoms and improving quality of life. Pre-clinical studies indicate that more frequent dosing exhibits enhanced efficacy. However, depending on the underlying mechanisms involved, it is possible that antitumor activity may require long term treatment and follow-up, e.g., over years rather than just the few weeks or months of most clinical trials. It is unlikely that future large scale IVC RCTs will be carried out due to the prohibitive costs. Nevertheless, smaller scale studies, if well designed, have the potential to contribute relevant and translatable findings to inform good clinical practice.

\section{AUTHOR CONTRIBUTIONS}

AC conceived and wrote the review. JC contributed clinical input.

\section{FUNDING}

AC was supported by a Health Research Council of New Zealand Sir Charles Hercus Health Research Fellowship (\#16/037).

Cameron, E., and Pauling, L. (1978). Supplemental ascorbate in the supportive treatment of cancer: reevaluation of prolongation of survival times in terminal human cancer. Proc. Natl. Acad. Sci. U.S.A. 75, 4538-4542. doi: 10.1073/pnas. 75.9.4538

Campbell, E. J., and Dachs, G. U. (2014). Current limitations of murine models in oncology for ascorbate research. Front. Oncol. 4:282. doi: 10.3389/fonc.2014. 00282

Campbell, E. J., Vissers, M. C., Bozonet, S., Dyer, A., Robinson, B. A., and Dachs, G. U. (2015). Restoring physiological levels of ascorbate slows tumor growth and moderates HIF-1 pathway activity in Gulo(-/-) mice. Cancer Med. 4, 303-314. doi: 10.1002/cam4.349

Campbell, E. J., Vissers, M. C., and Dachs, G. U. (2016a). Ascorbate availability affects tumor implantation-take rate and increases tumor rejection in Gulo-/mice. Hypoxia (Auckl.) 4, 41-52.

Campbell, E. J., Vissers, M. C., Wohlrab, C., Hicks, K. O., Strother, R. M., Bozonet, S. M., et al. (2016b). Pharmacokinetic and anti-cancer properties of high dose ascorbate in solid tumours of ascorbate-dependent mice. Free Radic. Biol. Med. 99, 451-462. doi: 10.1016/j.freeradbiomed.2016.08.027

Carr, A., and Frei, B. (1999a). Does vitamin C act as a pro-oxidant under physiological conditions? FASEB J. 13, 1007-1024.

Carr, A., Wohlrab, C., Young, P., and Bellomo, R. (2018). Stability of intravenous vitamin C solutions: a technical report. Crit. Care Resuscita (in press).

Carr, A. C., and Frei, B. (1999b). Toward a new recommended dietary allowance for vitamin $\mathrm{C}$ based on antioxidant and health effects in humans. Am. J. Clin. Nutr. 69, 1086-1107.

Carr, A. C., and Maggini, S. (2017). Vitamin C and immune function. Nutrients 9:E1211. doi: 10.3390/nu9111211

Carr, A. C., and McCall, C. (2017). The role of vitamin C in the treatment of pain: new insights. J. Transl. Med. 15:77. doi: 10.1186/s12967-017-1179-7

Carr, A. C., Vissers, M. C. M., and Cook, J. S. (2014). The effect of intravenous vitamin $\mathrm{C}$ on cancer- and chemotherapy-related fatigue and quality of life. Front. Oncol. 4:283. doi: 10.3389/fonc.2014.00283

Casciari, J. J., Riordan, H. D., Miranda-Massari, J. R., and Gonzalez, M. J. (2005). Effects of high dose ascorbate administration on L-10 tumor growth in guinea pigs. P R Health Sci. J. 24, 145-150. 
Cha, J., Roomi, M. W., Ivanov, V., Kalinovsky, T., Niedzwiecki, A., and Rath, M. (2011). Ascorbate depletion increases growth and metastasis of melanoma cells in vitamin C deficient mice. Exp. Oncol. 33, 226-230.

Cha, J., Roomi, M. W., Ivanov, V., Kalinovsky, T., Niedzwiecki, A., and Rath, M. (2013). Ascorbate supplementation inhibits growth and metastasis of B16FO melanoma and $4 \mathrm{~T} 1$ breast cancer cells in vitamin C-deficient mice. Int. J. Oncol. 42, 55-64. doi: 10.3892/ijo.2012.1712

Cha, J., Roomi, M. W., Kalinovsky, T., Niedzwiecki, A., and Rath, M. (2016). Lipoprotein(a) and vitamin C impair development of breast cancer tumors in Lp(a)+, Gulo-/- mice. Int. J. Oncol. 49, 895-902. doi: 10.3892/ijo.2016.3597

Chen, M. F., Yang, C. M., Su, C. M., and Hu, M. L. (2014). Vitamin C protects against cisplatin-induced nephrotoxicity and damage without reducing its effectiveness in C57BL/6 mice xenografted with Lewis lung carcinoma. Nutr. Cancer 66, 1085-1091. doi: 10.1080/01635581.2014.948211

Chen, P., Stone, J., Sullivan, G., Drisko, J. A., and Chen, Q. (2011). Anti-cancer effect of pharmacologic ascorbate and its interaction with supplementary parenteral glutathione in preclinical cancer models. Free Radic. Biol. Med. 51, 681-687. doi: 10.1016/j.freeradbiomed.2011.05.031

Chen, Q., Espey, M. G., Krishna, M. C., Mitchell, J. B., Corpe, C. P., Buettner, G. R., et al. (2005). Pharmacologic ascorbic acid concentrations selectively kill cancer cells: action as a pro-drug to deliver hydrogen peroxide to tissues. Proc. Natl. Acad. Sci. U.S.A. 102, 13604-13609. doi: 10.1073/pnas.0506390102

Chen, Q., Espey, M. G., Sun, A. Y., Lee, J. H., Krishna, M. C., Shacter, E., et al. (2007). Ascorbate in pharmacologic concentrations selectively generates ascorbate radical and hydrogen peroxide in extracellular fluid in vivo. Proc. Natl. Acad. Sci. U.S.A. 104, 8749-8754. doi: 10.1073/pnas.0702854104

Chen, Q., Espey, M. G., Sun, A. Y., Pooput, C., Kirk, K. L., Krishna, M. C., et al. (2008). Pharmacologic doses of ascorbate act as a prooxidant and decrease growth of aggressive tumor xenografts in mice. Proc. Natl. Acad. Sci. U.S.A. 105, 11105-11109. doi: 10.1073/pnas.0804226105

Chirino, Y. I., and Pedraza-Chaverri, J. (2009). Role of oxidative and nitrosative stress in cisplatin-induced nephrotoxicity. Exp. Toxicol. Pathol. 61, 223-242. doi: 10.1016/j.etp.2008.09.003

Choi, M. A., Kim, B. S., and Yu, R. (1999). Serum antioxidative vitamin levels and lipid peroxidation in gastric carcinoma patients. Cancer Lett. 136, 89-93. doi: 10.1016/S0304-3835(98)00312-7

Cieslak, J. A., and Cullen, J. J. (2015). Treatment of pancreatic cancer with pharmacological ascorbate. Curr. Pharm. Biotechnol. 16, 759-770. doi: 10.2174/ 138920101609150715135921

Cieslak, J. A., Sibenaller, Z. A., Walsh, S. A., Ponto, L. L., Du, J., Sunderland, J. J., et al. (2016). Fluorine-18-Labeled thymidine positron emission tomography (FLT-PET) as an index of cell proliferation after pharmacological ascorbatebased therapy. Radiat. Res. 185, 31-38. doi: 10.1667/RR14203.1

Cimmino, L., Dolgalev, I., Wang, Y., Yoshimi, A., Martin, G. H., Wang, J., et al. (2017). Restoration of TET2 function blocks aberrant self-renewal and leukemia progression. Cell 170, 1079.e20-1095.e20. doi: 10.1016/j.cell.2017.07.032

Clement, M. V., Ramalingam, J., Long, L. H., and Halliwell, B. (2001). The in vitro cytotoxicity of ascorbate depends on the culture medium used to perform the assay and involves hydrogen peroxide. Antioxid. Redox Signal. 3, 157-163. doi: 10.1089/152308601750100687

Cossey, L. N., Rahim, F., and Larsen, C. P. (2013). Oxalate nephropathy and intravenous vitamin C. Am. J. Kidney Dis. 61, 1032-1035. doi: 10.1053/j.ajkd. 2013.01.025

Creagan, E. T., Moertel, C. G., O’Fallon, J. R., Schutt, A. J., O’Connell, M. J., Rubin, J., et al. (1979). Failure of high-dose vitamin C (ascorbic acid) therapy to benefit patients with advanced cancer. A controlled trial. N. Engl. J. Med. 301, 687-690. doi: 10.1056/NEJM197909273011303

D'Andrea, G. M. (2005). Use of antioxidants during chemotherapy and radiotherapy should be avoided. CA Cancer J. Clin. 55, 319-321. doi: 10.3322/ canjclin.55.5.319

de Grooth, H. J., Manubulu-Choo, W. P., Zandvliet, A. S., Spoelstra-de Man, A. M. E., Girbes, A. R., Swart, E. L., et al. (2018). Vitamin-C pharmacokinetics in critically ill patients: a randomized trial of four intravenous regimens. Chest 153, 1368-1377. doi: 10.1016/j.chest.2018.02.025

Doskey, C. M., Buranasudja, V., Wagner, B. A., Wilkes, J. G., Du, J., Cullen, J. J., et al. (2016). Tumor cells have decreased ability to metabolize $\mathrm{H}_{2} \mathrm{O}_{2}$ : implications for pharmacological ascorbate in cancer therapy. Redox Biol. 10, 274-284. doi: 10.1016/j.redox.2016.10.010
Du, J., Cieslak, J. A. III, Welsh, J. L., Sibenaller, Z. A., Allen, B. G., Wagner, B. A., et al. (2015). Pharmacological ascorbate radiosensitizes pancreatic cancer. Cancer Res. 75, 3314-3326. doi: 10.1158/0008-5472.CAN-14-1707

Du, J., Cullen, J. J., and Buettner, G. R. (2012). Ascorbic acid: chemistry, biology and the treatment of cancer. Biochim. Biophys. Acta 1826, 443-457. doi: 10.1016/j. bbcan.2012.06.003

Du, J., Martin, S. M., Levine, M., Wagner, B. A., Buettner, G. R., Wang, S. H., et al. (2010). Mechanisms of ascorbate-induced cytotoxicity in pancreatic cancer. Clin. Cancer Res. 16, 509-520. doi: 10.1158/1078-0432.CCR-09-1713

Ebata, K. T., Mesh, K., Liu, S., Bilenky, M., Fekete, A., Acker, M. G., et al. (2017). Vitamin $\mathrm{C}$ induces specific demethylation of H3K9me2 in mouse embryonic stem cells via Kdm3a/b. Epigenet. Chromat. 10:36. doi: 10.1186/s13072-0170143-3

Emri, S., Kilickap, S., Kadilar, C., Halil, M. G., Akay, H., and Besler, T. (2012). Serum levels of alpha-tocopherol, vitamin C, beta-carotene, and retinol in malignant pleural mesothelioma. Asian Pac. J Cancer Prev. 13, 3025-3029. doi: 10.7314/APJCP.2012.13.7.3025

Englard, S., and Seifter, S. (1986). The biochemical functions of ascorbic acid. Annu. Rev. Nutr. 6, 365-406. doi: 10.1146/annurev.nu.06.070186.002053

Espey, M. G., Chen, P., Chalmers, B., Drisko, J., Sun, A. Y., Levine, M., et al. (2011). Pharmacologic ascorbate synergizes with gemcitabine in preclinical models of pancreatic cancer. Free Radic. Biol. Med. 50, 1610-1619. doi: 10.1016/ j.freeradbiomed.2011.03.007

Fain, O., Mathieu, E., and Thomas, M. (1998). Scurvy in patients with cancer. BMJ. 316, 1661-1662. doi: 10.1136/bmj.316.7145.1661

Fritz, H., Flower, G., Weeks, L., Cooley, K., Callachan, M., McGowan, J., et al. (2014). Intravenous vitamin $C$ and cancer: a systematic review. Integr. Cancer Ther. 13, 280-300. doi: 10.1177/1534735414534463

Fujita, K., Shinpo, K., Yamada, K., Sato, T., Niimi, H., Shamoto, M., et al. (1982). Reduction of adriamycin toxicity by ascorbate in mice and guinea pigs. Cancer Res. 42, 309-316.

Gao, P., Zhang, H., Dinavahi, R., Li, F., Xiang, Y., Raman, V., et al. (2007). HIF-dependent antitumorigenic effect of antioxidants in vivo. Cancer Cell 12, 230-238. doi: 10.1016/j.ccr.2007.08.004

Gillberg, L., Orskov, A. D., Liu, M., Harslof, L. B. S., Jones, P. A., and Gronbaek, K. (2017). Vitamin C - A new player in regulation of the cancer epigenome. Semin. Cancer Biol. 51, 59-67. doi: 10.1016/j.semcancer.2017.11.001

Goncalves, T. L., Benvegnu, D. M., Bonfanti, G., Frediani, A. V., and Rocha, J. B. (2009). Delta-Aminolevulinate dehydratase activity and oxidative stress during melphalan and cyclophosphamide-BCNU-etoposide (CBV) conditioning regimens in autologous bone marrow transplantation patients. Pharmacol. Res. 59, 279-284. doi: 10.1016/j.phrs.2008.12.005

Gonzalez, M. J., Miranda Massari, J. R., Duconge, J., Riordan, N. H., and Ichim, T. (2012). Schedule dependence in cancer therapy: intravenous vitamin $C$ and the systemic saturation hypothesis. J. Orthomol. Med. 27, 9-12.

Grasso, C., Fabre, M. S., Collis, S. V., Castro, M. L., Field, C. S., Schleich, N., et al. (2014). Pharmacological doses of daily ascorbate protect tumors from radiation damage after a single dose of radiation in an intracranial mouse glioma model. Front. Oncol. 4:356. doi: 10.3389/fonc.2014.00356

Guemouri, L., Artur, Y., Herbeth, B., Jeandel, C., Cuny, G., and Siest, G. (1991). Biological variability of superoxide dismutase, glutathione peroxidase, and catalase in blood. Clin. Chem. 37, 1932-1937.

Gunes-Bayir, A., and Kiziltan, H. S. (2015). Palliative vitamin C application in patients with radiotherapy-resistant bone metastases: a retrospective study. Nutr. Cancer 67, 921-925. doi: 10.1080/01635581.2015.1055366

Gupta, A., Bhatt, M. L., and Misra, M. K. (2009). Lipid peroxidation and antioxidant status in head and neck squamous cell carcinoma patients. Oxid. Med. Cell Longev. 2, 68-72. doi: 10.4161/oxim.2.2.8160

Gustafson, C. B., Yang, C., Dickson, K. M., Shao, H., Van Booven, D., Harbour, J. W., et al. (2015). Epigenetic reprogramming of melanoma cells by vitamin C treatment. Clin. Epigenet. 7:51. doi: 10.1186/s13148-015-0087-z

Haffner, M. C., Chaux, A., Meeker, A. K., Esopi, D. M., Gerber, J., Pellakuru, L. G., et al. (2011). Global 5-hydroxymethylcytosine content is significantly reduced in tissue stem/progenitor cell compartments and in human cancers. Oncotarget 2, 627-637. doi: 10.18632/oncotarget.316

Harris, H. R., Orsini, N., and Wolk, A. (2014). Vitamin C and survival among women with breast cancer: a meta-analysis. Eur. J Cancer 50, 1223-1231. doi: 10.1016/j.ejca.2014.02.013 
Herst, P. M., Broadley, K. W., Harper, J. L., and McConnell, M. J. (2012). Pharmacological concentrations of ascorbate radiosensitize glioblastoma multiforme primary cells by increasing oxidative DNA damage and inhibiting G2/M arrest. Free Radic. Biol. Med. 52, 1486-1493. doi: 10.1016/j. freeradbiomed.2012.01.021

Hirota, K., and Semenza, G. L. (2005). Regulation of hypoxia-inducible factor 1 by prolyl and asparaginyl hydroxylases. Biochem. Biophys. Res. Commun. 338, 610-616. doi: 10.1016/j.bbrc.2005.08.193

Hirsila, M., Koivunen, P., Gunzler, V., Kivirikko, K. I., and Myllyharju, J. (2003). Characterization of the human prolyl 4-hydroxylases that modify the hypoxiainducible factor. J. Biol. Chem. 278, 30772-30780. doi: 10.1074/jbc.M304982200

Hoffer, L. J., Levine, M., Assouline, S., Melnychuk, D., Padayatty, S. J., Rosadiuk, K., et al. (2008). Phase I clinical trial of i.v. ascorbic acid in advanced malignancy. Ann. Oncol. 19, 1969-1974. doi: 10.1093/annonc/mdn377

Hoffer, L. J., Robitaille, L., Zakarian, R., Melnychuk, D., Kavan, P., Agulnik, J., et al. (2015). High-dose intravenous vitamin C combined with cytotoxic chemotherapy in patients with advanced cancer: a Phase I-II clinical trial. PLoS One 10:e0120228. doi: 10.1371/journal.pone.0120228

Hosokawa, Y., Monzen, S., Yoshino, H., Terashima, S., Nakano, M., Toshima, K., et al. (2015). Effects of Xray irradiation in combination with ascorbic acid on tumor control. Mol. Med. Rep. 12, 5449-5454. doi: 10.3892/mmr.2015.4108

Huijskens, M. J., Wodzig, W. K., Walczak, M., Germeraad, W. T., and Bos, G. M. (2016). Ascorbic acid serum levels are reduced in patients with hematological malignancies. Results Immunol. 6, 8-10. doi: 10.1016/j.rinim.2016.01.001

Hunnisett, A., Davies, S., McLaren-Howard, J., Gravett, P., Finn, M., and GueretWardle, D. (1995). Lipoperoxides as an index of free radical activity in bone marrow transplant recipients. Prelimin. Obs. Biol. Trace Elem. Res. 47, 125-132. doi: 10.1007/BF02790109

Jonas, C. R., Puckett, A. B., Jones, D. P., Griffith, D. P., Szeszycki, E. E., Bergman, G. F., et al. (2000). Plasma antioxidant status after high-dose chemotherapy: a randomized trial of parenteral nutrition in bone marrow transplantation patients. Am. J. Clin. Nutr. 72, 181-189. doi: 10.1093/ajcn/72.1.181

Jozwiak, P., Ciesielski, P., Zaczek, A., Lipinska, A., Pomorski, L., Wieczorek, M., et al. (2017). Expression of hypoxia inducible factor lalpha and 2alpha and its association with vitamin C level in thyroid lesions. J. Biomed. Sci. 24:83. doi: 10.1186/s12929-017-0388-y

Kahn, S. A., and Lentz, C. W. (2015). Fictitious hyperglycemia: point-of-care glucose measurement is inaccurate during high-dose vitamin $\mathrm{C}$ infusion for burn shock resuscitation. J. Burn Care Res.. 36, e67-e71. doi: 10.1097/BCR. 0000000000000141

Kalita, S., Verma, A. K., and Prasad, S. B. (2014). Chlorambucil and ascorbic acid-mediated anticancer activity and hematological toxicity in Dalton's ascites lymphoma-bearing mice. Indian J. Exp. Biol. 52, 112-124.

Kawada, H., Sawanobori, M., Tsuma-Kaneko, M., Wasada, I., Miyamoto, M., Murayama, H., et al. (2014). Phase I clinical trial of intravenous L-ascorbic acid following salvage chemotherapy for relapsed B-cell non-Hodgkin's lymphoma. Tokai J. Exp. Clin. Med. 39, 111-115.

Khanzode, S. S., Khanzode, S. D., and Dakhale, G. N. (2003). Serum and plasma concentration of oxidant and antioxidants in patients of Helicobacter pylori gastritis and its correlation with gastric cancer. Cancer Lett. 195, 27-31. doi: 10.1016/S0304-3835(03)00147-2

Khanzode, S. S., Muddeshwar, M. G., Khanzode, S. D., and Dakhale, G. N. (2004). Antioxidant enzymes and lipid peroxidation in different stages of breast cancer. Free Radic. Res. 38, 81-85. doi: 10.1080/01411590310001637066

Kiziltan, H. S., Bayir, A. G., Demirtas, M., Meral, I., Taspinar, O., Eris, A. H., et al. (2014). Ascorbic-acid treatment for progressive bone metastases after radiotherapy: a pilot study. Altern. Ther. Health Med. 20(Suppl. 2), 16-20.

Klose, R. J., Kallin, E. M., and Zhang, Y. (2006). JmjC-domain-containing proteins and histone demethylation. Nat. Rev. Genet. 7, 715-727. doi: 10.1038/nrg1945

Koivunen, P., Hirsila, M., Gunzler, V., Kivirikko, K. I., and Myllyharju, J. (2004). Catalytic properties of the asparaginyl hydroxylase (FIH) in the oxygen sensing pathway are distinct from those of its prolyl 4-hydroxylases. J. Biol. Chem. 279, 9899-9904. doi: 10.1074/jbc.M312254200

Kroeze, L. I., van der Reijden, B. A., and Jansen, J. H. (2015). 5hydroxymethylcytosine: an epigenetic mark frequently deregulated in cancer. Biochim. Biophys. Acta 1855, 144-154. doi: 10.1016/j.bbcan.2015.01.001

Kudo, Y., Tateishi, K., Yamamoto, K., Yamamoto, S., Asaoka, Y., Ijichi, H., et al. (2012). Loss of 5-hydroxymethylcytosine is accompanied with malignant cellular transformation. Cancer Sci. 103, 670-676. doi: 10.1111/j.1349-7006. 2012.02213.x

Kuiper, C., Dachs, G. U., Munn, D., Currie, M. J., Robinson, B. A., Pearson, J. F., et al. (2014a). Increased tumor ascorbate is associated with extended diseasefree survival and decreased hypoxia-inducible factor-1 activation in human colorectal cancer. Front. Oncol. 4:10. doi: 10.3389/fonc.2014.00010

Kuiper, C., Vissers, M. C., and Hicks, K. O. (2014b). Pharmacokinetic modeling of ascorbate diffusion through normal and tumor tissue. Free Radic. Biol. Med. 77, 340-352. doi: 10.1016/j.freeradbiomed.2014.09.023

Kuiper, C., Molenaar, I. G., Dachs, G. U., Currie, M. J., Sykes, P. H., and Vissers, M. C. (2010). Low ascorbate levels are associated with increased hypoxiainducible factor-1 activity and an aggressive tumor phenotype in endometrial cancer. Cancer Res. 70, 5749-5758. doi: 10.1158/0008-5472.CAN-10-0263

Kuiper, C., and Vissers, M. C. (2014). Ascorbate as a co-factor for Fe- and 2oxoglutarate dependent dioxygenases: physiological activity in tumor growth and progression. Front. Oncol. 4:359. doi: 10.3389/fonc.2014.00359

Lawenda, B. D., Kelly, K. M., Ladas, E. J., Sagar, S. M., Vickers, A., and Blumberg, J. B. (2008). Should supplemental antioxidant administration be avoided during chemotherapy and radiation therapy? J. Natl. Cancer Inst. 100, 773-783. doi: 10.1093/jnci/djn148

Lawton, J. M., Conway, L. T., Crosson, J. T., Smith, C. L., and Abraham, P. A. (1985). Acute oxalate nephropathy after massive ascorbic acid administration. Arch. Intern. Med. 145, 950-951. doi: 10.1001/archinte.1985.00360050220044

Lee, J., Lee, G., Park, J. H., Lee, S., Yeom, C. H., Na, B., et al. (2012). Proteomic analysis of tumor tissue in CT-26 implanted BALB/C mouse after treatment with ascorbic acid. Cell. Mol. Biol. Lett. 17, 62-76. doi: 10.2478/s11658-0110035-7

Levine, M., Conry-Cantilena, C., Wang, Y., Welch, R. W., Washko, P. W., Dhariwal, K. R., et al. (1996). Vitamin C pharmacokinetics in healthy volunteers: evidence for a recommended dietary allowance. Proc. Natl. Acad. Sci. U.S.A. 93, 3704-3709. doi: 10.1073/pnas.93.8.3704

Lian, C. G., Xu, Y., Ceol, C., Wu, F., Larson, A., Dresser, K., et al. (2012). Loss of 5-hydroxymethylcytosine is an epigenetic hallmark of melanoma. Cell 150, 1135-1146. doi: 10.1016/j.cell.2012.07.033

Liu, M., Ohtani, H., Zhou, W., Orskov, A. D., Charlet, J., Zhang, Y. W., et al. (2016). Vitamin C increases viral mimicry induced by 5 -aza-2' -deoxycytidine. Proc. Natl. Acad. Sci. U.S.A. 113, 10238-10244. doi: 10.1073/pnas.1612262113

Low, F. M., Hampton, M. B., and Winterbourn, C. C. (2008). Peroxiredoxin 2 and peroxide metabolism in the erythrocyte. Antioxid. Redox Signal. 10, 1621-1630. doi: 10.1089 /ars.2008.2081

Lykkesfeldt, J., and Poulsen, H. E. (2010). Is vitamin C supplementation beneficial? Lessons learned from randomised controlled trials. Br. J. Nutr. 103, 1251-1259. doi: 10.1017/S0007114509993229

Ma, Y., Chapman, J., Levine, M., Polireddy, K., Drisko, J., and Chen, Q. (2014). High-dose parenteral ascorbate enhanced chemosensitivity of ovarian cancer and reduced toxicity of chemotherapy. Sci. Transl. Med. 6:222ra18. doi: 10.1126/ scitranslmed.3007154

Ma, Y., Sullivan, G. G., Schrick, E., Choi, I. Y., He, Z., Lierman, J., et al. (2013). A convenient method for measuring blood ascorbate concentrations in patients receiving high-dose intravenous ascorbate. J. Am. Coll Nutr. 32, 187-193. doi: 10.1080/07315724.2013.791167

Mahdavi, R., Faramarzi, E., Seyedrezazadeh, E., Mohammad-Zadeh, M., and Pourmoghaddam, M. (2009). Evaluation of oxidative stress, antioxidant status and serum vitamin C levels in cancer patients. Biol. Trace Elem. Res. 130, 1-6. doi: 10.1007/s12011-008-8309-2

Mamede, A. C., Pires, A. S., Abrantes, A. M., Tavares, S. D., Goncalves, A. C., Casalta-Lopes, J. E., et al. (2012). Cytotoxicity of ascorbic acid in a human colorectal adenocarcinoma cell line (WiDr): in vitro and in vivo studies. Nutr. Cancer 64, 1049-1057. doi: 10.1080/01635581.2012.713539

Manning, J., Mitchell, B., Appadurai, D. A., Shakya, A., Pierce, L. J., Wang, H., et al. (2013). Vitamin C promotes maturation of T-cells. Antioxid. Redox Signal. 19, 2054-2067. doi: 10.1089/ars.2012.4988

Marcus, S. L., Petrylak, D. P., Dutcher, J. P., Paietta, E., Ciobanu, N., Strauman, J., et al. (1991). Hypovitaminosis $C$ in patients treated with high-dose interleukin 2 and lymphokine-activated killer cells. Am. J. Clin. Nutr. 54(6 Suppl.), 1292S-1297S. doi: 10.1093/ajcn/54.6.1292s

Mayland, C. R., Bennett, M. I., and Allan, K. (2005). Vitamin C deficiency in cancer patients. Palliat Med. 19, 17-20. doi: 10.1191/0269216305pm970oa 
Mehdi, W. A., Zainulabdeen, J. A., and Mehde, A. A. (2013). Investigation of the antioxidant status in multiple myeloma patients: effects of therapy. Asian Pac. J. Cancer Prev. 14, 3663-3667. doi: 10.7314/APJCP.2013.14.6.3663

Mikirova, N., Casciari, J., Riordan, N., and Hunninghake, R. (2013). Clinical experience with intravenous administration of ascorbic acid: achievable levels in blood for different states of inflammation and disease in cancer patients. J. Transl. Med. 11:191. doi: 10.1186/1479-5876-11-191

Mikirova, N., Casciari, J., Rogers, A., and Taylor, P. (2012). Effect of high-dose intravenous vitamin $\mathrm{C}$ on inflammation in cancer patients. J. Transl. Med. 10, 189. doi: 10.1186/1479-5876-10-189

Mikirova, N., Riordan, N., and Casciari, J. (2016). Modulation of cytokines in cancer patients by intravenous ascorbate therapy. Med. Sci. Monit. 22, 14-25. doi: 10.12659/MSM.895368

Mingay, M., Chaturvedi, A., Bilenky, M., Cao, Q., Jackson, L., Hui, T., et al. (2017). Vitamin C-induced epigenomic remodelling in IDH1 mutant acute myeloid leukaemia. Leukemia 32, 11-20. doi: 10.1038/leu.2017.171

Minor, E. A., Court, B. L., Young, J. I., and Wang, G. (2013). Ascorbate induces Ten-eleven translocation (Tet) methylcytosine dioxygenase-mediated generation of 5-hydroxymethylcytosine. J. Biol. Chem. 288, 13669-13674. doi: 10.1074/jbc.C113.464800

Moertel, C. G., Fleming, T. R., Creagan, E. T., Rubin, J., O'Connell, M. J., and Ames, M. M. (1985). High-dose vitamin C versus placebo in the treatment of patients with advanced cancer who have had no prior chemotherapy. A randomized double-blind comparison. N. Engl. J. Med. 312, 137-141. doi: 10.1056/NEJM198501173120301

Monti, D. A., Mitchell, E., Bazzan, A. J., Littman, S., Zabrecky, G., Yeo, C. J., et al. (2012). Phase I evaluation of intravenous ascorbic acid in combination with gemcitabine and erlotinib in patients with metastatic pancreatic cancer. PLoS One 7:e29794. doi: 10.1371/journal.pone.0029794

Muhlhofer, A., Mrosek, S., Schlegel, B., Trommer, W., Rozario, F., Bohles, H., et al. (2004). High-dose intravenous vitamin C is not associated with an increase of pro-oxidative biomarkers. Eur. J. Clin. Nutr. 58, 1151-1158. doi: 10.1038/sj.ejcn. 1601943

Murata, A., Morishige, F., and Yamaguchi, H. (1982). Prolongation of survival times of terminal cancer patients by administration of large doses of ascorbate. Int. J. Vitam Nutr. Res. Suppl. 23, 103-113.

Nannya, Y., Shinohara, A., Ichikawa, M., and Kurokawa, M. (2014). Serial profile of vitamins and trace elements during the acute phase of allogeneic stem cell transplantation. Biol. Blood Marrow Transplant. 20, 430-434. doi: 10.1016/j. bbmt.2013.12.554

Nielsen, T. K., Hojgaard, M., Andersen, J. T., Jorgensen, N. R., Zerahn, B., Kristensen, B., et al. (2017). Weekly ascorbic acid infusion in castrationresistant prostate cancer patients: a single-arm phase II trial. Transl. Androl. Urol. 6, 517-528. doi: 10.21037/tau.2017.04.42

Nielsen, T. K., Hojgaard, M., Andersen, J. T., Poulsen, H. E., Lykkesfeldt, J., and Mikines, K. J. (2015). Elimination of ascorbic acid after high-dose infusion in prostate cancer patients: a pharmacokinetic evaluation. Basic Clin. Pharmacol. Toxicol. 116, 343-348. doi: 10.1111/bcpt.12323

Oak, A. S., Jaleel, T., Fening, K., Pavlidakey, P. G., and Sami, N. (2016). A case of scurvy associated with nilotinib. J. Cutan Pathol. 43, 725-726. doi: 10.1111/cup. 12715

Padayatty, S. J., Riordan, H. D., Hewitt, S. M., Katz, A., Hoffer, L. J., and Levine, M. (2006). Intravenously administered vitamin $C$ as cancer therapy: three cases. CMAJ 174, 937-942. doi: 10.1503/cmaj.050346

Padayatty, S. J., Sun, A. Y., Chen, Q., Espey, M. G., Drisko, J., and Levine, M. (2010). Vitamin C: intravenous use by complementary and alternative medicine practitioners and adverse effects. PLoS One 5:e11414. doi: 10.1371/journal.pone. 0011414

Padayatty, S. J., Sun, H., Wang, Y., Riordan, H. D., Hewitt, S. M., Katz, A., et al. (2004). Vitamin C pharmacokinetics: implications for oral and intravenous use. Ann. Int. Med. 140, 533-537. doi: 10.7326/0003-4819-140-7-200404060-00010

Park, J. H., Davis, K. R., Lee, G., Jung, M., Jung, Y., Park, J., et al. (2012). Ascorbic acid alleviates toxicity of paclitaxel without interfering with the anticancer efficacy in mice. Nutr. Res. 32, 873-883. doi: 10.1016/j.nutres.2012.09.011

Park, S., Ahn, E. S., Lee, S., Jung, M., Park, J. H., Yi, S. Y., et al. (2009). Proteomic analysis reveals upregulation of RKIP in S-180 implanted BALB/C mouse after treatment with ascorbic acid. J. Cell Biochem. 106, 1136-1145. doi: 10.1002/jcb. 22097
Parrow, N. L., Leshin, J. A., and Levine, M. (2013). Parenteral ascorbate as a cancer therapeutic: a reassessment based on pharmacokinetics. Antioxid. Redox Signal. 19, 2141-2156. doi: 10.1089/ars.2013.5372

Polireddy, K., Dong, R., Reed, G., Yu, J., Chen, P., Williamson, S., et al. (2017). High dose parenteral ascorbate inhibited pancreatic cancer growth and metastasis: mechanisms and a Phase I/IIa study. Sci. Rep. 7:17188. doi: 10.1038/s41598017-17568-8

Pollard, H. B., Levine, M. A., Eidelman, O., and Pollard, M. (2010). Pharmacological ascorbic acid suppresses syngeneic tumor growth and metastases in hormone-refractory prostate cancer. In Vivo 24, 249-255.

Pullar, J. M., Bayer, S., and Carr, A. C. (2018). Appropriate handling, processing and analysis of blood samples is essential to avoid oxidation of vitamin $\mathrm{C}$ to dehydroascorbic acid. Antioxidants 7:E29. doi: 10.3390/antiox7020029

Quinn, J., Gerber, B., Fouche, R., Kenyon, K., Blom, Z., and Muthukanagaraj, P. (2017). Effect of high-dose vitamin C infusion in a glucose-6-phosphate dehydrogenase-deficient patient. Case Rep. Med. 2017:5202606. doi: 10.1155/ 2017/5202606

Ramaswamy, G., and Krishnamoorthy, L. (1996). Serum carotene, vitamin A, and vitamin $\mathrm{C}$ levels in breast cancer and cancer of the uterine cervix. Nutr. Cancer 25, 173-177. doi: 10.1080/01635589609514439

Rasheed, M., Roberts, C. H., Gupta, G., Fisher, B. J., Leslie, K., Simmons, G. L., et al. (2017). Low plasma vitamin C levels in patients undergoing stem cell transplantation (Abstract). Biol. Blood Marrow Transpl. 23, S225-S226. doi: 10.1016/j.bbmt.2016.12.446

Raymond, Y. C., Glenda, C. S., and Meng, L. K. (2016). Effects of high doses of vitamin $\mathrm{C}$ on cancer patients in singapore: nine cases. Integr. Cancer Ther. 15, 197-204. doi: 10.1177/1534735415622010

Rees, D. C., Kelsey, H., and Richards, J. D. (1993). Acute haemolysis induced by high dose ascorbic acid in glucose-6-phosphate dehydrogenase deficiency. BMJ 306, 841-842. doi: 10.1136/bmj.306.6881.841

Reuter, S., Gupta, S. C., Chaturvedi, M. M., and Aggarwal, B. B. (2010). Oxidative stress, inflammation, and cancer: how are they linked? Free Radic. Biol. Med. 49, 1603-1616. doi: 10.1016/j.freeradbiomed.2010.09.006

Riordan, H. D., Casciari, J. J., Gonzalez, M. J., Riordan, N. H., Miranda-Massari, J. R., Taylor, P., et al. (2005). A pilot clinical study of continuous intravenous ascorbate in terminal cancer patients. PR Health Sci. J. 24, 269-276.

Riordan, H. D., Riordan, N. H., Jackson, J. A., Casciari, J. J., Hunninghake, R., Gonzalez, M. J., et al. (2004). Intravenous vitamin C as a chemotherapy agent: a report on clinical cases. PR Health Sci. J. 23, 115-118.

Robitaille, L., Mamer, O. A., Miller, W. H. Jr., Levine, M., Assouline, S., Melnychuk, D., et al. (2009). Oxalic acid excretion after intravenous ascorbic acid administration. Metabolism 58, 263-269. doi: 10.1016/j.metabol.2008. 09.023

Rouleau, L., Antony, A. N., Bisetto, S., Newberg, A., Doria, C., Levine, M., et al. (2016). Synergistic effects of ascorbate and sorafenib in hepatocellular carcinoma: new insights into ascorbate cytotoxicity. Free Radic. Biol. Med. 95, 308-322. doi: 10.1016/j.freeradbiomed.2016.03.031

Savini, I., Rossi, A., Pierro, C., Avigliano, L., and Catani, M. V. (2008). SVCT1 and SVCT2: key proteins for vitamin C uptake. Amino Acids 34, 347-355. doi: 10.1007/s00726-007-0555-7

Schoenfeld, J. D., Sibenaller, Z. A., Mapuskar, K. A., Wagner, B. A., CramerMorales, K. L., Furqan, M., et al. (2017). O2- and H2O2-Mediated Disruption of Fe metabolism causes the differential susceptibility of NSCLC and GBM Cancer cells to pharmacological ascorbate. Cancer Cell. 31, 487.e8-500.e8. doi: 10.1016/j.ccell.2017.02.018

Seely, D., Stempak, D., and Baruchel, S. (2007). A strategy for controlling potential interactions between natural health products and chemotherapy: a review in pediatric oncology. J. Pediatr. Hematol. Oncol. 29, 32-47. doi: 10.1097/MPH. 0b013e3180310521

Serrano, O. K., Parrow, N. L., Violet, P. C., Yang, J., Zornjak, J., Basseville, A., et al. (2015). Antitumor effect of pharmacologic ascorbate in the B16 murine melanoma model. Free Radic. Biol. Med. 87, 193-203. doi: 10.1016/j. freeradbiomed.2015.06.032

Sestili, P., Brandi, G., Brambilla, L., Cattabeni, F., and Cantoni, O. (1996). Hydrogen peroxide mediates the killing of U937 tumor cells elicited by pharmacologically attainable concentrations of ascorbic acid: cell death prevention by extracellular catalase or catalase from cocultured erythrocytes or fibroblasts. J. Pharmacol. Exp. Ther. 277, 1719-1725. 
Sharma, A., Tripathi, M., Satyam, A., and Kumar, L. (2009). Study of antioxidant levels in patients with multiple myeloma. Leuk Lymphoma 50, 809-815. doi: 10.1080/10428190902802323

Shenoy, N., Bhagat, T., Nieves, E., Stenson, M., Lawson, J., Choudhary, G. S., et al. (2017). Upregulation of TET activity with ascorbic acid induces epigenetic modulation of lymphoma cells. Blood Cancer J. 7:e587. doi: 10.1038/bcj.2017.65

Shinozaki, K., Hosokawa, Y., Hazawa, M., Kashiwakura, I., Okumura, K., Kaku, T., et al. (2011). Ascorbic acid enhances radiation-induced apoptosis in an HL60 human leukemia cell line. J. Radiat. Res. 52, 229-237. doi: 10.1269/jrr.10089

Simone, C. B. II, Simone, N. L., and Simone, V. (2007). Antioxidants and other nutrients do not interfere with chemotherapy or radiation therapy and can increase kill and increase survival, part 1. Altern. Ther. Health Med. 13, 22-28.

Song, M. H., Nair, V. S., and Oh, K. I. (2017). Vitamin C enhances the expression of IL17 in a Jmjd2-dependent manner. BMB Rep. 50, 49-54. doi: 10.5483/ BMBRep.2017.50.1.193

Stephenson, C. M., Levin, R. D., Spector, T., and Lis, C. G. (2013). Phase I clinical trial to evaluate the safety, tolerability, and pharmacokinetics of high-dose intravenous ascorbic acid in patients with advanced cancer. Cancer Chemother. Pharmacol. 72, 139-146. doi: 10.1007/s00280-013-2179-9

Takahashi, H., Mizuno, H., and Yanagisawa, A. (2012). High-dose intravenous vitamin C improves quality of life in cancer patients. Personal. Med. Universe. 2, 49-53. doi: 10.1016/j.pmu.2012.05.008

Takemura, Y., Satoh, M., Satoh, K., Hamada, H., Sekido, Y., and Kubota, S. (2010). High dose of ascorbic acid induces cell death in mesothelioma cells. Biochem. Biophys. Res. Commun. 394, 249-253. doi: 10.1016/j.bbrc.2010.02.012

Tang, Z., Du, X., Louie, R. F., and Kost, G. J. (2000). Effects of drugs on glucose measurements with handheld glucose meters and a portable glucose analyzer. Am. J. Clin. Pathol. 113, 75-86. doi: 10.1309/QAW1-X5XW-BVRQ-5LKQ

Torun, M., Yardim, S., Gonenc, A., Sargin, H., Menevse, A., and Simsek, B. (1995). Serum beta-carotene, vitamin E, vitamin C and malondialdehyde levels in several types of cancer. J. Clin. Pharm. Ther. 20, 259-263. doi: 10.1111/j.13652710.1995.tb00660.x

Tsukada, Y., Fang, J., Erdjument-Bromage, H., Warren, M. E., Borchers, C. H., Tempst, P., et al. (2006). Histone demethylation by a family of JmjC domaincontaining proteins. Nature 439, 811-816. doi: 10.1038/nature04433

Verrax, J., and Calderon, P. B. (2008). The controversial place of vitamin C in cancer treatment. Biochem. Pharmacol. 76, 1644-1652. doi: 10.1016/j.bcp.2008. 09.024

Verrax, J., and Calderon, P. B. (2009). Pharmacologic concentrations of ascorbate are achieved by parenteral administration and exhibit antitumoral effects. Free Radic. Biol. Med. 47, 32-40. doi: 10.1016/j.freeradbiomed.2009.02.016

Vollbracht, C., Schneider, B., Leendert, V., Weiss, G., Auerbach, L., and Beuth, J. (2011). Intravenous vitamin C administration improves quality of life in breast cancer patients during chemo-/radiotherapy and aftercare: results of a retrospective, multicentre, epidemiological cohort study in Germany. In Vivo 25, 983-990.

Wang, C., Lv, H., Yang, W., Li, T., Fang, T., Lv, G., et al. (2017). SVCT-2 determines the sensitivity to ascorbate-induced cell death in cholangiocarcinoma cell lines and patient derived xenografts. Cancer Lett. 398, 1-11. doi: 10.1016/j.canlet. 2017.03.039

Wang, G., Mustafi, S., Camarena, V., Volmar, C. H., Huff, T. C., Sant, D. W., et al. (2017). Vitamin C sensitizes melanoma to BET inhibitors. Cancer Res. 78, 572-583.

Wang, T., Chen, K., Zeng, X., Yang, J., Wu, Y., Shi, X., et al. (2011). The histone demethylases Jhdm $1 \mathrm{a} / \mathrm{lb}$ enhance somatic cell reprogramming in a vitaminC-dependent manner. Cell Stem Cell 9, 575-587. doi: 10.1016/j.stem.2011. 10.005

Weijl, N. I., Hopman, G. D., Wipkink-Bakker, A., Lentjes, E. G., Berger, H. M., Cleton, F. J., et al. (1998). Cisplatin combination chemotherapy induces a fall in plasma antioxidants of cancer patients. Ann. Oncol. 9, 1331-1337. doi: 10.1023/ A:1008407014084

Welsh, J. L., Wagner, B. A., van't Erve, T. J., Zehr, P. S., Berg, D. J., Halfdanarson, T. R., et al. (2013). Pharmacological ascorbate with gemcitabine for the control of metastatic and node-positive pancreatic cancer (PACMAN): results from a phase I clinical trial. Cancer Chemother. Pharmacol. 71, 765-775. doi: 10.1007/ s00280-013-2070-8

Wilkes, J. G., O’Leary, B. R., Du, J., Klinger, A. R., Sibenaller, Z. A., Doskey, C. M., et al. (2018). Pharmacologic ascorbate (P-AscH(-)) suppresses hypoxiainducible Factor-1alpha (HIF-1alpha) in pancreatic adenocarcinoma. Clin. Exp. Metastasis. 35, 37-51. doi: 10.1007/s10585-018-9876-z

Wilson, M. K., Baguley, B. C., Wall, C., Jameson, M. B., and Findlay, M. P. (2014). Review of high-dose intravenous vitamin $\mathrm{C}$ as an anticancer agent. Asia Pac. J. Clin. Oncol. 10, 22-37. doi: 10.1111/ajco.12173

Wohlrab, C., Phillips, E., and Dachs, G. U. (2017). Vitamin C transporters in cancer: current understanding and gaps in knowledge. Front. Oncol. 7:74. doi: 10.3389/fonc. 2017.00074

Wong, K., Thomson, C., Bailey, R. R., McDiarmid, S., and Gardner, J. (1994). Acute oxalate nephropathy after a massive intravenous dose of vitamin C. Aust. N. Z. J. Med. 24, 410-411. doi: 10.1111/j.1445-5994.1994.tb01477.x

Xia, J., Xu, H., Zhang, X., Allamargot, C., Coleman, K. L., Nessler, R., et al. (2017). Multiple myeloma tumor cells are selectively killed by pharmacologically-dosed ascorbic acid. EBioMedicine 18, 41-49. doi: 10.1016/j.ebiom.2017.02.011

Yang, G., Yan, Y., Ma, Y., and Yang, Y. (2017). Vitamin C at high concentrations induces cytotoxicity in malignant melanoma but promotes tumor growth at low concentrations. Mol. Carcinog. 56, 1965-1976. doi: 10.1002/mc.22654

Yeom, C. H., Jung, G. C., and Song, K. J. (2007). Changes of terminal cancer patients' health-related quality of life after high dose vitamin $\mathrm{C}$ administration. J. Korean Med. Sci. 22, 7-11. doi: 10.3346/jkms.2007.22.1.7

Yeom, C. H., Lee, G., Park, J. H., Yu, J., Park, S., Yi, S. Y., et al. (2009). High dose concentration administration of ascorbic acid inhibits tumor growth in $\mathrm{BALB} / \mathrm{C}$ mice implanted with sarcoma 180 cancer cells via the restriction of angiogenesis. J. Transl. Med. 7:70. doi: 10.1186/1479-5876-7-70

Yin, R., Mao, S. Q., Zhao, B., Chong, Z., Yang, Y., Zhao, C., et al. (2013). Ascorbic acid enhances Tet-mediated 5-methylcytosine oxidation and promotes DNA demethylation in mammals. J. Am. Chem. Soc. 135, 10396-10403. doi: 10.1021/ ja4028346

Yun, J., Mullarky, E., Lu, C., Bosch, K. N., Kavalier, A., Rivera, K., et al. (2015). Vitamin C selectively kills KRAS and BRAF mutant colorectal cancer cells by targeting GAPDH. Science 350, 1391-1396. doi: 10.1126/science.aaa5004

Zhang, Z. Z., Lee, E. E., Sudderth, J., Yue, Y., Zia, A., Glass, D., et al. (2016). Glutathione depletion, pentose phosphate pathway activation, and hemolysis in erythrocytes protecting cancer cells from vitamin C-induced oxidative stress. J. Biol. Chem. 291, 22861-22867. doi: 10.1074/jbc.C116.748848

Zhao, H., Zhu, H., Huang, J., Zhu, Y., Hong, M., Zhu, H., et al. (2018). The synergy of vitamin $\mathrm{C}$ with decitabine activates TET2 in leukemic cells and significantly improves overall survival in elderly patients with acute myeloid leukemia. Leuk Res. 66, 1-7. doi: 10.1016/j.leukres.2017.12.009

Conflict of Interest Statement: The authors declare that the research was conducted in the absence of any commercial or financial relationships that could be construed as a potential conflict of interest.

Copyright (c) 2018 Carr and Cook. This is an open-access article distributed under the terms of the Creative Commons Attribution License (CC BY). The use, distribution or reproduction in other forums is permitted, provided the original author(s) and the copyright owner(s) are credited and that the original publication in this journal is cited, in accordance with accepted academic practice. No use, distribution or reproduction is permitted which does not comply with these terms. 